\title{
Immune regulation in renal inflammation
}

\author{
Katrin Neumann ${ }^{1,2}\left(\right.$ Gisa Tiegs $^{1,2}$
}

Received: 28 August 2020 / Accepted: 16 November 2020 / Published online: 26 January 2021

(c) The Author(s) 2021

\begin{abstract}
Renal inflammation, induced by autoantigen recognition or toxic drugs, leads to renal tissue injury and decline in kidney function. Recent studies have demonstrated the crucial role for regulatory $\mathrm{T}$ cells in suppressing pathogenic adaptive but also innate immune responses in the inflamed kidney. However, there is also evidence for other immune cell populations with immunosuppressive function in renal inflammation. This review summarizes mechanisms of immune cell regulation in immune-mediated glomerulonephritis and acute and chronic nephrotoxicity.
\end{abstract}

Keywords Immune regulation - Immune-mediated glomerulonephritis $\cdot$ Nephrotoxicity $\cdot$ Regulatory T cells $\cdot$ ILC2

\section{Introduction}

Renal inflammation contributes to a multitude of acute and chronic kidney diseases. These include autoimmune kidney diseases such as several forms of glomerulonephritis (GN), which typically result from an overshooting adaptive immune response to autoantigens. However, also more toxic insults, such as ischemia-reperfusion injury (IRI) and cisplatin or adriamycin nephrotoxicity, seem to be mediated by cells of the innate and adaptive immune system. Immunity and inflammation are controlled by immune regulatory mechanisms in order to restore homeostasis. Intriguingly, immune regulation is also elicited in response to IRI or nephrotoxicity induced by cytostatic agents (Sharma and Kinsey 2018). In contrast, autoimmunity results from dysfunction of cells that mediate immunoregulation (Sakaguchi et al. 2008). These cells, originally described to suppress autoimmunity, are named regulatory $\mathrm{T}$ cells (Tregs) and represent a subset of $\mathrm{CD}^{+} \mathrm{T}$ helper (Th) cells expressing the forkhead box P3 (Foxp3) transcription factor as well as high levels of the interleukin (IL)-2 high-affinity receptor IL-2R $\alpha$ or CD25 (Sakaguchi et al. 2008). There are two main

Katrin Neumann

kat.neumann@uke.de

1 Institute of Experimental Immunology and Hepatology, University Medical Center Hamburg-Eppendorf, Hamburg, Germany

2 Hamburg Center for Translational Immunology, University Medical Center Hamburg-Eppendorf, Hamburg, Germany subsets of Tregs depending on their place of origin. Natural Tregs (nTregs) develop in the thymus by recognition of selfantigens presented by major histocompatibility complex class II (MHCII) molecules in a process called positive selection. In the periphery, $n$ Tregs regulate activation of effector $\mathrm{T}$ cells recognizing self-antigens and play a crucial role in induction of tolerance against foreign antigens derived from commensal bacteria or food. In contrast, induced Tregs (iTregs) are generated in the periphery by differentiation of naïve $\mathrm{CD} 4^{+}$ Foxp $3^{-} \mathrm{T}$ cells into $\mathrm{CD} 4^{+}$Foxp $^{+}$Tregs during antigenic stimulation in the presence of IL-2 and transforming growth factor $\beta$ (TGF $\beta$ ) (Sakaguchi et al. 2008).

In patients, several autoimmune GNs have been associated with aberrant Treg responses, yet displaying heterogeneous mechanisms of dysregulation of immunosuppression with respect to the particular disease. For example, in autoimmune anti-glomerular basement membrane (antiGBM) GN or Goodpasture's disease, where autoimmunity develops against the non-collagenous domain of the $\alpha 3$-chain of type IV collagen ( $\alpha 3$ [IV]NC1), antigen-specific regulatory $\mathrm{CD} 4^{+} \mathrm{CD} 25^{\mathrm{hi}} \mathrm{T}$ cells, capable of suppressing Th1 responses, were absent during active disease but significantly elevated during remission and might be responsible for the rarity of relapses in anti-GBM disease (Salama et al. 2003). Moreover, anti-neutrophil cytoplasmic antibody (ANCA)associated vasculitis, which can be linked with rapidly progressive glomerulonephritis, was described to correlate with increased numbers of Tregs during remission (Morgan et al. 2010). However, Tregs from ANCA patients seemed to possess decreased suppressive function (Morgan et al. 
2010; Rimbert et al. 2011; Free et al. 2013). Systemic lupus erythematosus (SLE) affects multiple organs including lung and kidney. Lupus nephritis has been identified as a major risk factor for a poor prognosis of SLE (Bagavant and $\mathrm{Fu}$ 2009). Conflicting results have been shown regarding Treg numbers in SLE patients. While most of the studies reported a decreased proportion of Tregs, others described normal or even increased rates (reviewed in Miyara et al. 2011). Reduced Treg numbers have been positively correlated with disease activity in SLE patients and were associated with an impaired capacity of T cells to produce IL-2 (Humrich et al. 2010; Alcocer-Varela and Alarcon-Segovia 1982; Von Spee-Mayer et al. 2016), which is indispensable for peripheral Treg survival and expansion (Fontenot et al. 2005; D'Cruz and Klein 2005; Setoguchi et al. 2005). Based on these observations, clinical studies on low-dose IL-2 therapy in SLE patients were initiated. Interestingly, lowdose IL-2 expanded nTregs expressing high levels of CD25, retained their suppressive capacity and reduced disease activity in SLE patients (Von Spee-Mayer et al. 2016; He et al. 2016). Finally, reduced Treg frequencies were also shown in patients with immunoglobulin (Ig)A nephropathy (Jin et al. 2018; Lin et al. 2012; Yang et al. 2017), the most frequent cause of primary GN. Here, altered expression of microRNAs (miR) has been associated with Treg deficiency. While elevated expression of miR-133a/133b might prevent FOXP3 translation and thus, Treg differentiation (Jin et al. 2018), miR-155 deficiency might inhibit maturation of Tregs in patients with IgA nephropathy (Yang et al. 2017).

However, most of the studies analyzing immune regulatory mechanisms in renal inflammation were conducted in animal models and therefore, will be summarized here.

\section{Immune regulation of immune-mediated GN by regulatory $\mathrm{T}$ cells}

\section{Nephrotoxic nephritis}

A multitude of studies regarding immune regulation in GN have been conducted in the model of rapidly progressive or crescentic GN induced by antibodies raised in sheep or rabbit against protein preparations of the murine glomerular basement membrane (GBM). This model, also referred to as nephrotoxic nephritis (NTN), is not a model of autoimmune GN since glomerular injury develops in response to deposited sheep or rabbit anti-mouse GBM antibodies and not to an endogenous autoantigen. However, NTN is mediated by Th1 and Th17 responses (Kurts et al. 2013), thereby representing a paradigm for immune-mediated GN that allows to study cellular and molecular mechanisms, which activate and regulate immune responses during GN.
Histological analysis of kidneys from nephritic mice revealed crescent formation in glomeruli within 7 days following NTN induction along with infiltration of monocytes/macrophages and $\mathrm{T}$ cells. Renal dendritic cells (DCs) have been described as tissue-resident professional antigen-presenting cells (APCs), which are located in the tubulointerstitium (Krüger et al. 2004). They acquire a pathogenic phenotype during NTN and trigger inflammatory $\mathrm{CD} 4^{+} \mathrm{T}$ cell activation, thereby driving pathology of GN (Hochheiser et al. 2011). A pathogenic role of $\mathrm{CD} 4^{+} \mathrm{T}$ cells in NTN was first demonstrated in CD4-deficient mice (Tipping et al. 1998) and in rats after $\mathrm{CD}^{+}{ }^{+} \mathrm{T}$ cell depletion (Huang et al. 1994). CD $4^{+} \mathrm{T}$ cell activation resulted in establishment of renal Th1 (Kitching et al. 1999a, 1999b; Phoon et al. 2008) and Th17 immune responses (Paust et al. 2009; Steinmetz et al. 2011; Odobasic et al. 2011), which aggravated NTN. Adoptive transfer experiments with $\mathrm{CD} 4{ }^{+} \mathrm{CD} 25^{+}$regulatory $\mathrm{T}$ cells were the first to show a protective role of Tregs in the NTN model. Transfer of these cells decreased proteinuria and crescent formation, reduced renal infiltration of $\mathrm{T}$ cells and macrophages and suppressed the Th1 response (Wolf et al. 2005). Later, two independent studies reported an immunosuppressive role of endogenous Foxp $3^{+}$Tregs during NTN by using depletion of regulatory T cell (DEREG) mice that express the diphtheria toxin receptor under control of the Foxp3 promoter, thereby allowing selective depletion of Foxp $3^{+}$Tregs by diphtheria toxin injection (Ooi et al. 2011; Paust et al. 2011). Interestingly, renal inflammation provoked a continuous increase of Tregs over time in the tubulointerstitium and periglomerular space. Moreover, Tregs from nephritic mice were more suppressive in vitro than those from naïve animals (Ooi et al. 2011). Treg depletion resulted in an aggravated course of GN and an enhanced renal and systemic Th1 response. Although both studies showed differences regarding the effect of Treg depletion on the Th17 response and on mouse anti-sheep antibody titers, both observed an increase of renal effector T cells and macrophages, all primarily located within interstitial and periglomerular areas (Ooi et al. 2011; Paust et al. 2011). In addition, an alternative approach demonstrated that in vivo expansion of endogenous Tregs using IL-2/anti-IL-2 monoclonal antibody $(\mathrm{mAb})$ complexes protected mice from glomerular injury during NTN (Klinge et al. 2019) (Fig. 1).

\section{ANCA-associated anti-myeloperoxidase GN}

Autoimmune disease results from loss of central tolerance to specific autoantigens. In a murine model of ANCAassociated anti-myeloperoxidase (MPO) GN, autoreactive MPO-specific $\mathrm{CD}^{+}{ }^{+} \mathrm{T}$ cells (Gan et al. 2013) and $\mathrm{CD} 8^{+} \mathrm{T}$ cells (Chang et al. 2017) were shown to mediate glomerular injury. In this model, depletion of Tregs by anti-CD25 $\mathrm{mAb}$ enhanced the frequencies of MPO-specific IFN $\gamma$ - and 


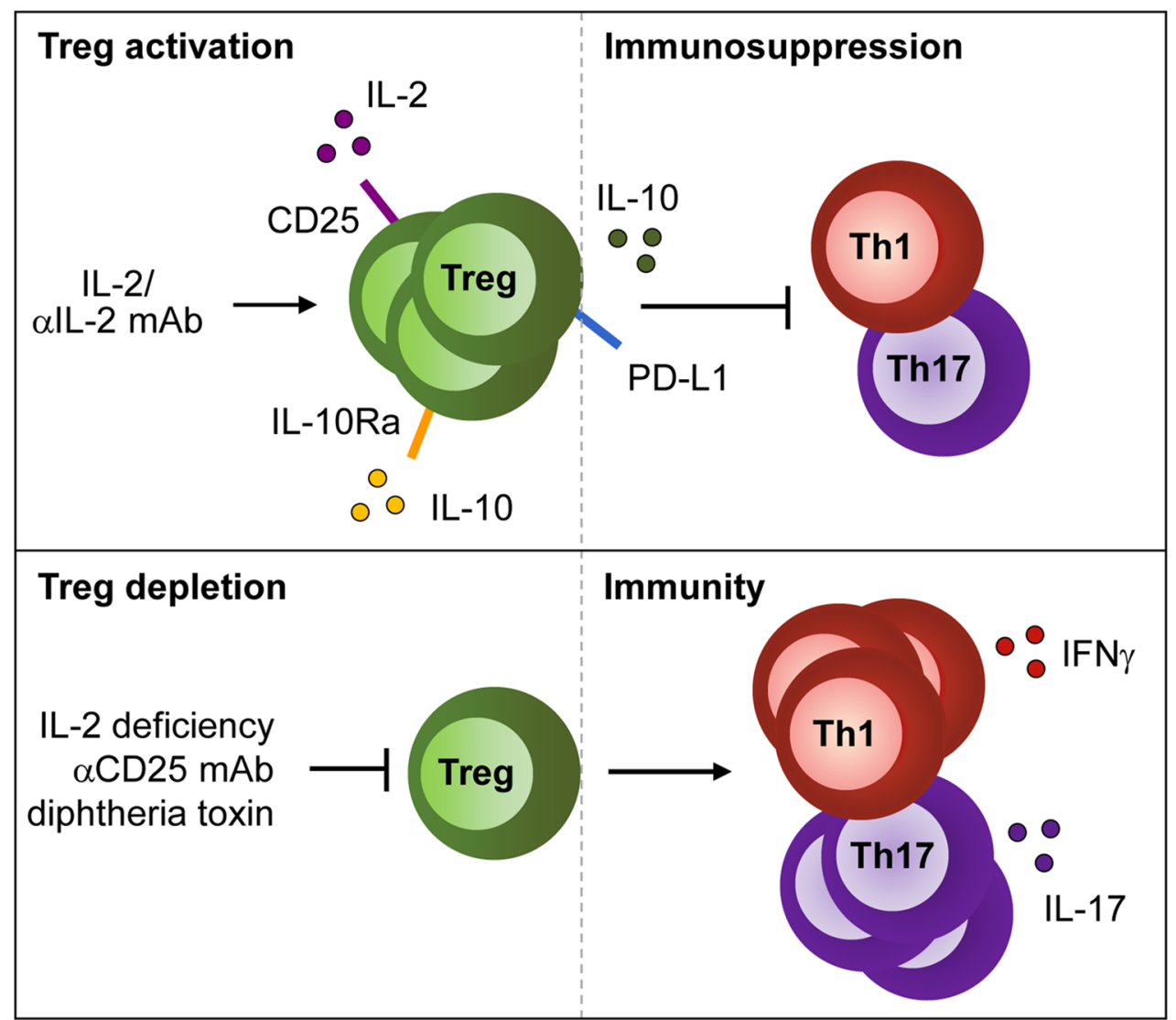

Fig. 1 Mechanisms of Treg activation and depletion in immunemediated GN. Treg activation and function is supported by IL-2, IL-10 and the IL-2/anti-IL-2 mAb complex in immune-mediated GN

IL-17A-expressing $\mathrm{T}$ cells and aggravated glomerular disease, thereby demonstrating the importance of Tregs in the maintenance of tolerance against the MPO autoantigen (Tan et al. 2013) (Fig. 1).

\section{Anti-glomerular basement membrane GN}

Autoimmune diseases are typically associated with specific human leukocyte antigen (HLA) alleles coding for MHCII molecules crucial for antigen presentation. Goodpasture's disease or anti-GBM GN is an HLA-linked autoimmune renal disorder associated with HLA-DR15 whereas the HLA-DR1 allele was linked with protection (Phelps and Rees 1999). AntiGBM GN is characterized by $\mathrm{CD} 4^{+} \mathrm{T}$ cells and antibodies directed against the Goodpasture autoantigen $\alpha 3(\mathrm{IV}) \mathrm{NC} 1$ of the GBM (Cairns et al. 2003). In humanized HLA-DR15 transgenic mice (Ooi et al. 2017) or in DBA/1 mice (Hünemörder et al. 2015), immunization with the autoantigen resulted in renal expansion of $\alpha 3$ (IV)NC1-specific $\mathrm{CD} 4{ }^{+} \mathrm{T}$ cells that produced IFN $\gamma$ or IL-17A and mediated development of crescentic GN. In the humanized mouse model, HLA-DR1 co-expression provided immune tolerance. Protection from glomerular disease thereby suppressing the inflammatory Th1 and Th17 response. In contrast, Treg depletion due to IL-2 deficiency or blockage of CD25 increases Th1- and Th17-mediated immunity

in HLA-DR15/DR1 double transgenic mice was mediated by autoantigen-specific $\mathrm{CD} 4^{+}$Foxp $3^{+}$Tregs, which expanded upon immunization and secreted tolerogenic cytokines (Ooi et al. 2017). Treg depletion in DBA/1-DEREG mice during immunization aggravated glomerular injury and induced autoantibody production and expansion of autoantigen-specific renal effector $\mathrm{CD}^{+} \mathrm{T}$ cells indicating a protective effect of Tregs during development of autoimmunity. However, in vivo expansion of Tregs with IL-2/anti-IL-2 mAb complexes in DBA/1-DEREG mice with established anti-GBM GN failed to prevent loss of kidney function and autoantibody titers were even increased (Klinge et al. 2019) (Fig. 1).

This observation might be explained by an impaired Treg function during chronic stages of anti-GBM GN. Tregs are a highly heterogeneous $\mathrm{T}$ cell population whose stability is regulated by certain surface molecules, cytokines and other environmental factors (Min 2017). For example, Treg stability depends on the local cytokine milieu. While IL-2 and its induced phosphorylation of the transcription factor STAT5 were shown to be essential for Treg stability and proliferation, TNF $\alpha$ decreased Foxp3 phosphorylation and thereby destabilized Tregs (Nie et al. 2013). In addition, in 
the presence of inflammatory cytokines, Foxp $3^{+}$Tregs were found to express IL-17 and the Th17-associated transcription factor ROR $\gamma$ t. This plasticity was accompanied by a reversible loss of immunosuppressive function depending on the stimulus (Beriou et al. 2009). Moreover, the methylation status of the Foxp3 promoter (Floess et al. 2007; Polansky et al. 2008), polyubiquitination and degradation of Foxp3 (Chen et al. 2013) and expression levels of anti-apoptotic Bcl-2 (Wang et al. 2012) have been identified to affect Treg stability. Thus, identification of mechanisms responsible for loss of tolerogenic Treg function during anti-GBM GN might unravel targets for future therapies.

\section{Systemic lupus erythematosus}

SLE is a systemic autoimmune disease, which is frequently associated with GN, named lupus nephritis. SLE results from a breakdown of tolerance to ubiquitous nuclear antigens including double-stranded DNA (Rahman and Isenberg 2008). IL-17-producing T cells have been associated with the disease in patients and lupus-prone mice (Crispín and Tsokos 2010). Moreover, impaired IL-2 production was observed in SLE patients (Linker-Israeli et al. 1983) and lupus-prone mice (Dauphinée et al. 1981). Pathogenicity of IL-2 deficiency was proven by infection of MRL/lpr mice with a vaccinia recombinant virus-based vector system expressing the IL-2 gene leading to prolonged survival, decreased autoantibody titers, as well as attenuated kidney interstitial infiltration and intraglomerular proliferation (Gutierrez-Ramos et al. 1990).

Peripheral Foxp $3^{+}$Treg survival and proliferation strictly depend on IL-2 (Fontenot et al. 2005; Setoguchi et al. 2005) and absence of IL-2 signaling in mice causes autoimmune disorders (Malek et al. 2002; Setoguchi et al. 2005). Studies in lupus-prone New Zealand Black $\times$ New Zealand White $(\mathrm{NZB} / \mathrm{W}) \mathrm{F} 1$ mice revealed that the ratio of $\mathrm{CD}^{+}{ }^{+} \mathrm{Foxp}^{+}$ Tregs to $\mathrm{CD}^{+}{ }^{+}$Foxp3 ${ }^{-}$conventional $\mathrm{T}$ cells declined in lymphoid organs of these animals. Further, the percentage of Tregs expressing the IL-2 receptor CD25 decreased with advancing disease, thereby resembling the phenotype of Tregs in IL-2-deficient mice. Interestingly, Tregs from NZB/W F1 mice were functionally intact and IL-2 treatment, which favored Treg proliferation compared to conventional $\mathrm{T}$ cells, improved proteinuria and survival (Humrich et al. 2010). In another study, NZB/W F1 mice were treated with the IL-2/anti-IL-2 mAb complex, which decreased the frequencies of renal and splenic IFN $\gamma^{+}$and IL- $17 \mathrm{~A}^{+} \mathrm{CD} 4^{+} \mathrm{T}$ cells, reduced autoantibody levels and attenuated glomerular and tubular injury (Yan et al. 2017). Likewise, lupus-prone MRL/lpr mice also featured IL-2 deficiency and restored IL-2 production ameliorated GN (Song et al. 2010). In summary, these studies demonstrated the importance of IL-2 for a functional Treg compartment that ensures tolerance against autoantigens driving SLE (Fig. 1).
In SLE patients, elevated levels of IL-23 were shown, a cytokine that induced IL-17 production in patient-derived T cells while IL-2 expression was limited. Interestingly, IL-23 receptor-deficient MRL/lpr mice displayed attenuated lupus nephritis associated with an increased expression of IL-2 while IL-17 was reduced (Dai et al. 2017). Hence, blockade of IL-23 will not only downregulate the inflammatory IL-17 response but could also increase IL-2 signaling and thereby potentially Treg expansion in patients with SLE.

\section{Heterogeneity of renal Tregs in immune-mediated GN}

A frequent observation is that Tregs from nephritic mice are equally or even more suppressive compared to those from naïve animals (Ooi et al. 2011; Paust et al. 2011). A possible explanation is that Tregs change their phenotype depending on the local cytokine milieu, expand and infiltrate into the inflamed organ to specifically suppress the corresponding local pro-inflammatory $\mathrm{T}$ helper (Th) cell response (Krebs and Steinmetz 2016). For example, in a co-culture system of $\mathrm{CD}^{+}{ }^{+}$Foxp $^{-}$responder $\mathrm{T}$ cells and Foxp $3^{+}$Tregs, those isolated from lymph nodes of nephritic NTN mice produced more of the anti-inflammatory cytokine IL-10 and showed an increased capacity to suppress responder $\mathrm{T}$ cell proliferation and production of pro-inflammatory cytokines compared to Tregs from naïve animals (Ooi et al. 2011).

Recently, a series of studies provided evidence for the existence of specialized Treg subsets, which express a Th subtype-specific transcription factor in addition to Foxp3 and suppress the corresponding Th cell response (Krebs and Steinmetz 2016). During Th1 inflammation, IFN $\gamma$ was shown to upregulate the Th1 transcription factor T-bet and the chemokine receptor CXCR3 in Tregs, thereby supporting homeostasis, migration and function of Tregs under inflammatory conditions to ensure proper control of Th1 immunity (Koch et al. 2009). Moreover, CXCR3-deficient Tregs failed to control Th1-mediated liver inflammation because of impaired organ infiltration but without losing their immunosuppressive capacity (Erhardt et al. 2011). In NTN, T-bet ${ }^{+}$Foxp $^{+}$Tregs (Treg1) were shown to accumulate in kidneys of nephritic mice. A Treg-specific knockout of T-bet in Foxp3 ${ }^{\mathrm{Cre}} \mathrm{xT}$-bet ${ }^{\mathrm{f} / \mathrm{fl}}$ mice resulted in an increased renal Th1 immunity, while the IL-17 response remained unchanged and aggravated NTN. Again, in vitro suppression assays demonstrated intact function of Treg1. However, reduced frequencies of Tregs were detectable in kidneys of Foxp3 ${ }^{\mathrm{Cre}} \mathrm{xT}$-bet ${ }^{\mathrm{t} / \mathrm{fl}}$ mice indicating impaired trafficking of T-bet-deficient Tregs most likely due to lack of CXCR3 expression (Nosko et al. 2017). Likewise, renal Treg infiltration was compromised in Foxp $3{ }^{\mathrm{Cre}} \mathrm{XCXCR}^{\mathrm{ff} / \mathrm{fl}}$ mice (Paust et al. 2016), which also developed more severe NTN, 
demonstrating the importance of CXCR3 expression on Th1 subtype-specific Tregs to control renal Th1 immunity.

Subtype-specific Tregs also regulate Th17 immune responses without affecting Th1 immunity. Foxp $3^{+}$Treg 17 cells express one of the master transcription factors of Th17 cells, STAT3, as well as the Th17 cell-specific chemokine receptor CCR6. Foxp3 ${ }^{\mathrm{Cre}} \mathrm{xStat} 3^{\mathrm{f} / \mathrm{fl}}$ mice, which lack Treg17 cells, were more susceptible towards crescentic GN in the NTN model (Kluger et al. 2014a) and towards SLE in a mouse model inducible by pristine (Kluger et al. 2016a). Treg17-deficient animals showed impaired renal trafficking of Tregs and increased Th17 responses (Kluger et al. 2014a, 2016a). Foxp $3^{+}$Tregs can also express ROR $\gamma t$ (Lochner et al. 2008), the second master transcription factor critical for development of Th17 cells. These cells, called biTregs, rapidly Hexpanded in kidney and spleen during NTN (Kluger et al. 2016b). In contrast to Treg17 cells, which do not express IL-17 (Kluger et al. 2014a), biTregs produced IL-17 in addition to the anti-inflammatory cytokine IL-10 (Osorio et al. 2008; Kluger et al. 2016b). BiTregs were present in Treg17-deficient mice and constitute an independent, bifunctional Treg subset. In line with this, adoptive transfer of biTregs suppressed NTN, while cell-specific deletion of ROR $\gamma \mathrm{t}$ in Foxp ${ }^{\mathrm{Cre}} \mathrm{xRorc}^{\mathrm{f} / \mathrm{fl}}$ mice resulted in significant protection from NTN, indicating a pro-inflammatory role of endogenous biTregs most likely due to their production of IL-17 (Kluger et al. 2016b). A detailed description of these Th subtype-specific Tregs is given elsewhere in this volume.

\section{Immune regulation of acute and chronic nephrotoxicity by regulatory $T$ cells}

Besides their well-defined role as regulators of immunemediated kidney injury, Tregs also suppress nephrotoxicity due to toxic organ damage. Nephrotoxicity can be induced by the chemotherapeutic agents cisplatin and adriamycin. Moreover, a common complication of kidney transplantation is renal ischemia-reperfusion injury (IRI), which develops in response to restoration of blood flow and reoxygenation of the previously ischemic tissue and may induce acute kidney injury (AKI). These agents or insults do not primarily activate the immune system. Rather, they induce necrotic cell death of renal tissue cells, which secondarily results in activation of the innate immune response. In addition, AKI can be associated with sepsis, the systemic inflammatory response to infection, which is still a challenge in intensive care units. Sepsis- or toxicity-related sterile inflammation is mediated by pathogen- or damage-associated molecular pattern released by dying cells, pattern-recognition receptors such as toll-like receptors, inflammasome activation, inflammatory cytokine and chemokine expression which induce activation and accumulation of neutrophils and mononuclear phagocytic cells into renal tissue (Hutton et al. 2016; Anders 2016). However, the adaptive immune system, although not activated by specific autoantigens during sterile inflammation, is also critically involved in AKI, as mice deficient in T cells, particularly in $\mathrm{CD} 4^{+} \mathrm{T}$ cells, were shown to be protected from post-ischemic renal injury (Burne et al. 2001; Jang and Rabb 2015). Similar results were obtained for cisplatin nephrotoxicity (Liu et al. 2006). Hence, it seems likely that Tregs regulate the corresponding effector $\mathrm{CD} 4^{+} \mathrm{T}$ cells via their bystander activity probably induced by a local cytokine milieu.

\section{Renal ischemia-reperfusion injury}

The role of $\mathrm{CD} 4^{+} \mathrm{CD} 25^{+}$Foxp $3^{+}$Tregs for IRI in mice has been demonstrated by depletion of these cells using anti-CD25 mAb PC61, which aggravates the severity of tubular necrosis, kidney damage and inflammation (Kinsey et al. 2009). In another approach, $\mathrm{Ragl}^{-/-}$mice, which lack $\mathrm{T}$ and $\mathrm{B}$ cells, were reconstituted with lymph node (LN) cells from either wild-type or scurfy mice, which lack Foxp3 expression and therefore Foxp $3^{+}$Tregs and then subjected to IRI. Exacerbation of renal IRI in $\mathrm{Ragl}^{-/-}$mice was more pronounced following adoptive transfer of LN cells from scurfy mice compared to those from wild-type animals. Co-transfer of scurfy LN cells together with wild-type Tregs blunted this effect. Treg transfer before induction of IRI prevented accumulation of neutrophils, macrophages and $\mathrm{CD} 4^{+} \mathrm{T}$ cells in the kidney during reperfusion. Interestingly, adoptive transfer of wildtype Tregs protected $\mathrm{Ragl}^{-/-}$mice from mild kidney IRI and inhibited renal neutrophil accumulation, demonstrating that Tregs suppress innate immune cells in absence of adaptive immunity (Kinsey et al. 2009). In a therapeutic approach, the IL-2/anti-IL-2 mAb complex was administered to wildtype mice, which expanded Foxp $3^{+}$Tregs in kidney and spleen, inhibited renal inflammation and damage in response to reperfusion injury and was also effective upon curative treatment (Kim et al. 2013) (Fig. 2).

Interestingly, IL-2 upregulates expression of the IL-33 receptor ST2 on CD4 ${ }^{+}$T cells (Sharma et al. 2011). IL-33 is an alarmin, which is induced in the kidney in response to renal IRI and seems to be involved in IRI pathophysiology (Liang et al. 2017; Ferhat et al. 2018). Moreover, IL-33 has been shown to support Treg recruitment and stability during inflammation (Schiering et al. 2014) and ST2 ${ }^{+}$Tregs, also called "repair" Tregs, were found to regulate local immune responses to tissue injury (Panduro et al. 2016; Zhang et al. 2017a, b). As discussed before, IL-2 is crucial for Treg stability and therefore, it was hypothesized that IL-2 and IL-33 might cooperate to enhance Treg function in the kidney in response to renal IRI (Stremska et al. 2017). Indeed, co-injection of IL-2 and IL-33 significantly increased expansion of Tregs in blood and spleen in contrast to 


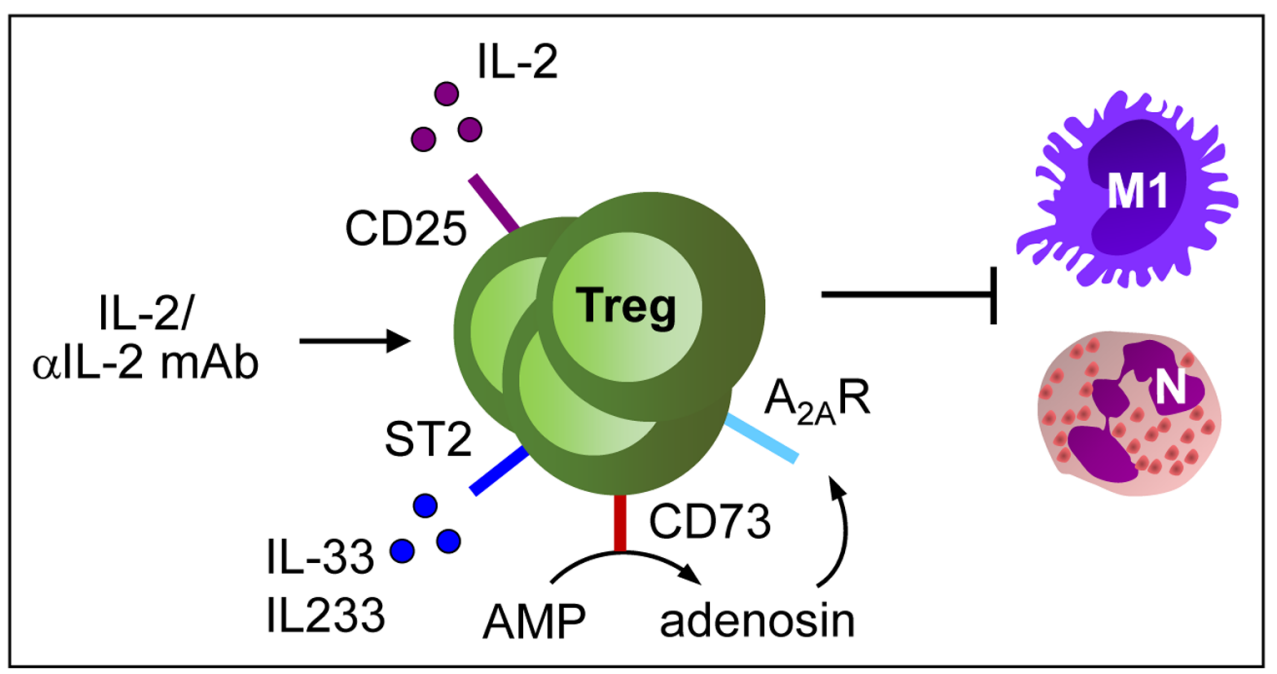

Fig. 2 Mechanisms of Treg activation in acute and chronic nephrotoxicity. Application of the IL-2/anti-IL-2 mAb complex as well as the cytokines IL-2, IL-33 or IL-233 induce $c$ and expansion and protect against tis-

IL-2 or IL-33 treatment alone and protected mice from renal IRI. The authors generated a novel hybrid cytokine, IL-233, bearing IL-2 and IL-33 activities in a single molecule, which was even more effective against IRI than co-application of IL-2 and IL-33. The hybrid cytokine increased Treg numbers also in the kidney, in particular in response to IRI. Interestingly, IL-233 induced a shift of Treg numbers from spleen to kidney in response to IRI, suggesting that IL-233 enhanced the mobilization of Tregs into the inflamed organ. Moreover, administration of the hybrid cytokine to mice increased the suppressive function of splenic Tregs in vitro in a suppression assay and in vivo against renal IRI in adoptive transfer experiments (Stremska et al. 2017). Recently, immune cell landscaping of Tregs isolated from kidneys after IRI revealed a tissue-resident Treg signature characterized by gene expression of ST2, amphiregulin (AREG) CTLA-4 and KLRG1. Pre-treatment of mice with IL-2/anti-IL-2 mAb complex/IL-33 strongly expanded renal Tregs and protected against tissue damage and development of fibrosis. Further, transcriptional profiling of Tregs derived from mice after AKI or during renal fibrosis showed differential expression of genes associated with regeneration and angiogenesis or hyperactivation and fibrosis depending on the inflammatory environment (Do Valle Duraes et al. 2020) (Fig. 2).

\section{Drug-induced nephrotoxic injury}

One dose-limiting toxicity of the chemotherapeutic drug cisplatin is induction of AKI whereas adriamycin induces chronic kidney disease (CKD) in rodent models. In both cases, nephrotoxicity is associated with production of proinflammatory cytokines and activation of innate immune cells such as neutrophils and macrophages (Manohar sue damage in acute and chronic nephrotoxicity by inhibiting innate immune responses. $\mathrm{N}$ : neutrophils, M1: M1 macrophages

and Leung 2018; Lee and Harris 2011). Both wild-type and athymic nude (nu/nu) mice, which lack mature $\mathrm{T}$ cells, were sensitive towards cisplatin nephrotoxicity, although nu/nu mice showed a better overall survival (Lee et al. 2010). Adoptive transfer of CD4 ${ }^{+} \mathrm{CD} 25^{+}$ Tregs protected nu/nu mice from cisplatin-induced renal injury by inhibition of TNF $\alpha$ and IL- $1 \beta$ production as well as macrophage accumulation in the kidney. Likewise, depletion of CD4 ${ }^{+} \mathrm{CD} 25^{+}$Tregs by anti-CD25 mAb aggravated kidney damage in wild-type mice (Lee et al. 2010). Hence, similar to AKI induced by IRI, CD $4^{+}$ $\mathrm{CD}_{25}{ }^{+}$Tregs suppressed acute nephrotoxicity in the absence of adaptive immunity. Moreover, pretreatment of mice with the hybrid cytokine IL-233, which increased ST2-expressing Tregs, protected mice from cisplatininduced nephrotoxicity (Stremska et al. 2017) (Fig. 2).

Similar studies were performed in the mouse model of adriamycin-induced CKD where T and B cell-deficient severe combined immunodeficiency (scid) mice were protected from glomerular and interstitial injury following reconstitution with $\mathrm{CD}^{+}{ }^{+} \mathrm{CD} 25^{+}$Tregs (Mahajan et al. 2006). Moreover, adoptive transfer of Foxp3-transduced $\mathrm{CD}^{+}{ }^{+} \mathrm{T}$ cells prevented adriamycin nephropathy and interstitial accumulation of $\mathrm{T}$ cells and macrophages (Wang et al. 2006). In addition, Treg expansion induced by administration of the IL-2/anti-IL-2 mAb complex (Polhill et al. 2012) or IL-233 (Stremska et al. 2017; Sabapathy et al. 2019) protected mice from CKD. IL-233 treatment preserved renal function and fibrosis when given either before or even at very late time points after induction of CKD, which correlated with induction of reparative mechanisms in kidneys of adriamycin-treated mice. The protective effect of IL-233 regarding renal inflammation, 
injury and fibrosis was blunted by administration of anti-CD25 mAb PC61, which depleted Tregs in spleen but not in kidneys (Sabapathy et al. 2019) (Fig. 2).

\section{Mechanisms of Treg-mediated immune regulation in renal inflammation}

Multiple mechanisms have been proposed for Tregmediated immunosuppression including contact-dependent mechanisms and soluble factors. These involve the cell surface molecules CTLA-4, CD25, PD-L1, TIGIT, LAG-3 TIM-3 and CD73/CD39, the cytokines IL-10, TGF $\beta$ and IL-35, as well as adenosine, cyclic (c)AMP and the cytotoxic molecule granzyme B (detailed reviewed in Shevach 2009; Josefowicz et al. 2012). Treg-dependent mechanisms of renal immunosuppression were widely studied in models of immune-mediated GN and the molecules most frequently investigated were anti-inflammatory cytokine IL-10 and the co-inhibitory molecule programmed-death ligand (PD-L)1.

\section{IL-10}

One important player of Treg-mediated immunosuppression is the anti-inflammatory cytokine IL-10, which is released from Tregs to suppress immune responses and therefore, might protect against autoimmunity. First evidence for a role of IL-10 in renal immune regulation derived from IL-10-deficient mice that showed an elevated Th1 response and developed more severe NTN (Kitching et al. 2000). However, the cellular source of IL-10 remained still elusive. To detect IL-10-producing cell populations in kidneys of nephritic NTN mice, we used double-knockin reporter mice, which allowed detection of IL-10/GFP as well as Foxp3/mRFP (FIR x tiger mice) (Ostmann et al. 2013). Seven days after NTN induction, we determined a significant increase of IL- $10^{+}$Foxp $3^{+}$Tregs in kidneys of nephritic FIR x tiger mice compared to healthy controls. Moreover, elevated frequencies of renal IL-10-expressing Th cells, DCs, macrophages and B cells were also detected in nephritic FIR $x$ tiger mice, indicating that other cell populations besides Tregs produced IL-10 in response to renal inflammation. To analyze the role of endogenous IL- $10^{+}$Tregs during NTN, we generated Foxp3 $3^{\mathrm{Cre}} \times \mathrm{XIL}-10^{\mathrm{fl} / \mathrm{fl}}$ mice. These mice developed more severe NTN than control mice assessed by increased glomerular crescent formation and albuminuria and an elevated Th17 immune response. However, Treg frequencies remained unaltered in inflamed kidneys of Foxp $3^{\mathrm{Cre}} \mathrm{XIL}-10^{\mathrm{fl} / \mathrm{fl}}$ mice. The importance of Treg-derived IL-10 was further confirmed by adoptive transfer experiments with Tregs from IL-10-deficient mice, which failed to prevent NTN in contrast to wild-type Tregs (Ostmann et al. 2013). IL-10-deficient Tregs did also not protect from renal IRI in $\operatorname{Rag}^{-/-}$mice (Kinsey et al. 2009), here by insufficient suppression of the innate rather than adaptive immunity (Fig. 1).

Foxp $3{ }^{\mathrm{Cre}} \mathrm{xIL}-10 \mathrm{Ra}{ }^{\mathrm{fl} / \mathrm{fl}}$ mice developed a spontaneous hyper-Th17 immune response compared to control mice. Following NTN induction, systemic and renal Th17 immunity was further boosted and crescentic GN as well as renal immune cell infiltration were aggravated. While Treg trafficking remained unaffected in the knockout animals, Tregs from Foxp ${ }^{\mathrm{Cre}} \mathrm{xIL}-10 \mathrm{Ra}^{\mathrm{fl} / \mathrm{fl}}$ mice showed a reduced ability to suppress effector $\mathrm{T}$ cell proliferation and IL-17 production in vitro. Moreover, IL-10Ra-deficient Tregs released less IL-10 in vitro and in vivo compared to respective controls (Diefenhardt et al. 2018). Hence, this study provided evidence for a feed-forward loop, in which IL-10Ra signaling mediates IL-10 secretion by Tregs that controls the renal Th17 immune response during NTN (Fig. 1).

As mentioned above, also $\mathrm{CD}_{19}{ }^{+} \mathrm{B}$ cells produced IL-10 in response to NTN (Ostmann et al. 2013). Indeed, IL- $10^{+}$regulatory $B$ cells have been implicated in the control of inflammation (Mauri and Bosma 2012). However, pathology of NTN was comparable in CD $19{ }^{\mathrm{Cre}} \mathrm{xIL}-10^{\mathrm{f} / \mathrm{fl}}$ and control mice (Kluger et al. 2014b). Along this line, IL-10producing $\mathrm{B}$ cells were unable to prevent the clinical course of lupus nephritis in MRL/lpr mice (Teichmann et al. 2012), indicating that B cell-derived IL-10 has no immunosuppressive function in GN.

\section{Co-inhibitory pathways}

Co-inhibitory pathways induce inhibitory signals in $\mathrm{T}$ cells and are crucial for the maintenance of peripheral tolerance. One negative co-stimulator receptor expressed on activated $\mathrm{T}$ cells is programed cell death-1 (PD-1), which binds to its ligands PD-L1 and PD-L2. While PD-L2 is exclusively expressed by hematopoietic cells such as activated DCs and macrophages, PD-L1 is expressed by hematopoietic and non-hematopoietic cells and can be further induced by pro-inflammatory cytokines such as IFN $\gamma$ (Keir et al. 2008). Recently, inappropriate expression of PD-L1 by tumor cells has been recognized as a target for cancer treatment, which resulted in clinical development of immune checkpoint inhibitors to fight cancer immune tolerance (Okazaki and Honjo 2007). The PD-1/PD-L1 pathway mediates immune regulation and tolerance either by direct inactivation of effector T cells (Freeman et al. 2000) or by induction and maintenance of peripheral Tregs (Francisco et al. 2009).

The PD-1/PD-L1 pathway has been implicated in immune regulation of renal diseases. A single nucleotide polymorphism in the PD-1 gene was associated with increased susceptibility of patients towards SLE (Prokunina et al. 2002). Studies in mice revealed that aged PD-1-deficient mice develop lupuslike GN (Nishimura et al. 1999). Moreover, in experimental 
autoimmune GN in rats, stimulation of the PD-1/PD-L1 pathway with a PD-L1/Fc fusion protein reduced kidney disease and renal inflammatory cell infiltration (Reynolds et al. 2012). Likewise, activation of the PD-1/PD-L1 axis using a PD-L1-Ig attenuated the pro-inflammatory cytokine response and renal injury in lupus-prone mice (Liao et al. 2017). On the other hand, inhibition of the PD-1/PD-L1 pathway using an anti-PD-L1 antibody aggravated lupus nephritis in NZB/W F1 mice and increased their mortality rate. However, antibodymediated blockade of PD-1 prevented lupus nephritis, probably by depleting $\mathrm{CD} 4{ }^{+} \mathrm{PD}-1^{\text {high }} \mathrm{T}$ cells that released high amounts of IFN $\gamma$ (Kasagi et al. 2010). Anti-PD-1 mAb treatment also increased renal macrophage infiltration and worsened glomerular and tubulointerstitial injury and renal dysfunction in adriamycin-induced CKD (Qin et al. 2006). Further, administration of PD-L1- or PD-L2-blocking mAbs and genetic deficiency of either PD-1 ligand exacerbated inflammation, renal function and tubular necrosis in the model of kidney IRI. In this study, experiments using bone marrow chimeric mice revealed that PD-L1 expressed on non-hematopoietic cells was critical for resistance to AKI. In addition, neutralization of either PD-1 ligand blunted the protective effect of adoptively transferred Tregs towards kidney IRI (Jaworska et al. 2015). Accordingly, in the NTN model, mice lacking either PD-L1 or PD-L2 showed increased renal pathology, loss of renal function and inflammatory leukocyte infiltrates. Here, PD-L1 expression on hematopoietic but not on parenchymal cells was responsible for aggravation of NTN (Menke et al. 2007). However, the specific PD-L1-expressing immune cell subtype that mediates the protective effect of PD-L1 in NTN remains to be determined. Since the PD-1/PD-L1 pathway contributes to Treg-mediated control of inflammation by induction and maintenance of Tregs (Francisco et al. 2009), we asked whether Tregs might be responsible for PD-L1-mediated protection in NTN. Interestingly, frequencies of PD-L1 ${ }^{+}$and PD $-1^{+}$Foxp ${ }^{+}$Tregs increased in kidneys of nephritic mice, suggesting a function of the PD-1/PD-L1 pathway in Tregmediated immune regulation in NTN (Neumann et al. 2019). To investigate the Treg response in absence of PD-1/PD-L1 signaling, we used PD-L1-deficient $\left(C d 274^{-/-}\right)$mice. PD-L1 was shown to be involved in T-cell development (Keir et al. 2005) and Treg induction (Francisco et al. 2009). However, we observed that $C d 274^{-/-}$mice showed similar frequencies of Helios ${ }^{+}$and neuropilin- ${ }^{+}$Foxp $3^{+}$Tregs compared to wild-type mice, thereby excluding developmental defects of thymus-derived Tregs in $C d 274^{-/-}$mice. Moreover, we detected increased frequencies of Foxp $3^{+}$Tregs in kidneys of nephritic $C d 274^{-/-}$mice, demonstrating that neither Treg proliferation nor Treg infiltration into the inflamed kidney were compromised in the absence of PD-1/PD-L1 signaling. However, analysis of renal and systemic immunity revealed that the Th1 response but not the Th17 response, was up-regulated in absence of PD-L1, which resulted in more severe NTN assessed by enhanced crescent formation and albuminuria. In order to rule out any influence of the genetic deletion of $C d 274$ on renal inflammation and injury, we blocked PD-L1 in NTN-treated wild-type mice using a specific $\mathrm{mAb}$ and obtained similar results as observed in nephritic $C d 274^{-/-}$mice. Hence, genetic deletion or mAbmediated blockade of PD-L1 increased Th1 immunity and aggravated NTN despite elevated frequencies of Foxp $3^{+}$Tregs in the inflamed kidney. Therefore, we further analyzed the phenotype and function of PD-L1-deficient Foxp $3^{+}$Tregs in homeostasis and renal inflammation. Gene expression profiling of FACS-sorted Foxp $3^{+}$Tregs isolated from naïve and NTNtreated Foxp3-reporter mice (FIR $\mathrm{x}$ tiger and FIR $\mathrm{x}$ tiger $\mathrm{x}$ $C d 274^{-/-}$mice) revealed a distinct gene expression profile of PD-L1-negative Tregs compared to PD-L1-expressing Tregs even in homeostasis. Most importantly, in nephritic mice, PD-L1 ${ }^{-}$Tregs showed decreased expression of genes related to Treg function such as $I l 10$ and $G z m B$ that were otherwise increased in response to kidney inflammation. Moreover, gene expression of the high affinity IL-2 receptor CD25 was maintained at high levels in PD-L1 ${ }^{+}$Tregs from nephritic mice but was down-regulated in PD-L1 ${ }^{-}$Tregs, indicating instability of PD-L1-deficient Tregs under inflammatory conditions. Functional analysis of the immunosuppressive activity of Tregs from nephritic $C d 274^{-1-}$ and wild-type mice revealed a decreased capacity of PD-L1 ${ }^{-}$Tregs to suppress effector T cell proliferation in vitro and an inability to prevent NTN upon adoptive transfer in vivo. Hence, Tregs exhibited an impaired immunosuppressive function during NTN in the absence of PD-L1 (Neumann et al. 2019) (Fig. 1).

Like the PD-1/PD-L1 pathway, T-cell immunoglobulin and mucin protein-3 (Tim3) and its ligand galectin-9 (Gal9) negatively regulate pro-inflammatory immune responses (Chen and Flies 2013). Tim-3 was shown to exert a protective function in NTN since administration of a blocking anti-Tim-3 $\mathrm{mAb}$ led to increased renal $\mathrm{T}$ cell and macrophage infiltration and aggravated NTN (Schroll et al. 2010). Furthermore, Gal-9 treatment reduced renal infiltration of Th1 and Th17 cells in anti-GBM GN and ameliorated renal injury (Zhang et al. 2014), indicating that in addition to PD-1/PD-L1, other co-inhibitory pathways may also regulate crescentic GN.

\section{CD39/CD73 and adenosine}

Tregs highly express the cell surface ectonucleotidases CD39 and CD73 to synthesize the anti-inflammatory mediator adenosine by degradation of extracellular ATP, which is a pro-inflammatory danger signal released by dying cells during tissue injury. CD39 and CD73 sequentially 
dephosphorylate extracellular ATP into its metabolites ADP and AMP (CD39) and AMP into adenosine (CD73). Adenosine binds to its receptor $\mathrm{A}_{2 \mathrm{~A}} \mathrm{R}$ expressed by immune effector cells, which results in anti-inflammatory signaling by elevation of intracellular cAMP levels (de Oliveira Bravo et al. 2016; Trautmann 2009).

The anti-inflammatory potency of $\mathrm{A}_{2 \mathrm{~A}} \mathrm{R}$ agonists has been analyzed in the kidney where they prevented renal IRI (Okusa et al. 1999). Likewise, an antagonist for the pro-inflammatory ATP receptor P2X7 has been shown to ameliorate kidney dysfunction and inflammation in renal IRI. Interestingly, the protective effect of the $\mathrm{P} 2 \mathrm{X} 7$ antagonist was mediated via Treg expansion since depletion of these cells using the anti-CD25 mAb PC61 abrogated the beneficial effect of the antagonist (Koo et al. 2017). One study analyzed the role of CD73 and $A_{2 A} R$ expressed by Tregs for renal damage in kidney IRI. In contrast to adoptively transferred wild-type Tregs, CD73-deficient or $\mathrm{A}_{2 \mathrm{~A}} \mathrm{R}$-deficient Tregs failed to protect mice from IRI-induced renal damage (Kinsey et al. 2012). Therefore, Treg-generated adenosine may act on innate immune cell activation induced by IRI and in an autocrine fashion on the Tregs themselves (Fig. 2). The mechanism of this feedback loop seemed to depend on $\mathrm{A}_{2 \mathrm{~A}} \mathrm{R}$-dependent enhanced surface expression of PD-1 on Tregs since their protective effect upon adoptive transfer was inhibited by pre-incubation with a blocking anti-PD-1 mAb. Thus, both the ability to generate and to respond to adenosine was required for Tregs to suppress kidney IRI through a PD-1dependent mechanism (Kinsey et al. 2012). In contrast, by using reciprocal bone marrow chimera of CD73-deficient and wild-type mice, it has been demonstrated that parenchymal but not hematopoietic expression of CD73 was responsible for inhibition of kidney IRI since $C d 73^{-/-}$recipients showed elevated levels of plasma creatinine and more severe tubular damage compared to wild-type recipients. These results were substantiated by showing that mice with a specific deletion of CD73 in proximal tubular epithelial cells (PTECs) were more sensitive towards renal inflammation and injury compared to several other cell-specific CD73 knockouts, indicating that CD73 expressed by PTECs is crucial for protection from kidney IRI (Sung et al. 2017).

\section{Renal iTreg induction by tolerogenic DCs and M2 macrophages}

Besides thymus-derived nTregs also iTregs, which differentiate from naïve Foxp3 ${ }^{-} \mathrm{CD}^{+} \mathrm{T}$ cells in the periphery, are crucial for the maintenance of peripheral tolerance and for immunosuppression during inflammation. Two subsets of APCs, namely tolerogenic DCs and M2 macrophages, have been described to be important for iTreg induction. Tolerogenic DCs are characterized by low expression of MHCII and co-stimulatory molecules, which has been shown to favor iTreg induction (Apostolou et al. 2004; Kretschmer et al. 2005; Domogalla et al. 2017). Tolerogenic DCs were found to induce iTregs by production of IL-10 (Akbari et al. 2001; Wakkach et al. 2003; Levings et al. 2005) or TGF $\beta$ (Travis et al. 2007). There are different subsets of DCs identified that promote iTreg development in secondary lymphoid organs including plasmacytoid DCs and CD103 ${ }^{+}$DCs (Ochando et al. 2006; Irla et al. 2010; Coombes et al. 2007).

In the kidney, a subset of basic leucine zipper ATFlike transcriptional factor 3 (Batf3)-dependent CD103 ${ }^{+}$ DCs was found to be crucial for renal iTreg induction and accumulation in crescentic GN. Absence of this DC subset in mice lacking Batf3 resulted in reduced renal Treg numbers and an aggravated course of GN (Evers et al. 2016). Several factors promote the tolerogenic phenotype of DCs and thus, iTreg induction, including IL-10 (Tai et al. 2011), vitamin D (Ferreira et al. 2014), or inhibition of nuclear factor

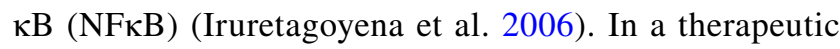
approach, adoptive transfer of tolerogenic DCs, generated in vitro in presence of a NFKB inhibitor and pulsed with the antigen MPO, decreased established antigen-specific antiMPO T-cell immunity and glomerular injury in the mouse model of autoimmune anti-MPO GN. Mechanistically, tolerogenic DCs induced IL-10-producing Tregs in MPOimmunized mice. In co-culture experiments, the tolerogenic DCs generated IL- $10^{+}$Foxp $3^{+}$Tregs from CD4 ${ }^{+}$Foxp $^{-} \mathrm{T}$ cells via inducible costimulator (ICOS). The protective effect of tolerogenic DCs on anti-MPO GN was blunted when $\mathrm{CD} 4^{+}$Foxp $^{+}$Tregs were depleted in vivo. When Tregs, expanded by tolerogenic DCs in vitro, were adoptively transferred into mice with anti-MPO GN, they suppressed anti-MPO immunity and GN via IL-10, as demonstrated by neutralization experiments with an anti-IL-10 receptor antibody. The authors suggested that autoantigen-loaded tolerogenic DCs might be a novel treatment option for antiMPO GN (Odobasic et al. 2019).

Alternatively activated M2 macrophages are characterized by expression of the mannose receptor and the antiinflammatory cytokine IL-10. M2 macrophage polarization occurs in response to various stimuli including the cytokines IL-4, IL-13, IL-10 and TGF $\beta$ (Gordon Immunity 2010). Human M2 macrophages, generated in vitro in presence of IL-4/IL-10/TGF $\beta$, were shown to induce a TGF $\beta$-dependent differentiation of Foxp $3^{+}$Tregs from naïve $\mathrm{CD} 4^{+} \mathrm{T}$ cells (Schmidt et al. 2016). In another study, M-CSF-induced M2 macrophages favored iTreg induction, which mediated their immunosuppressive function by expression of TGF $\beta$ (Savage et al. 2008).

In general, renal macrophages have been described to exacerbate kidney injury (Nikolic-Paterson et al. 2001; Schlondorff et al. 2008). However, there is some evidence that M2 macrophages have beneficial effects on disease 
pathology. Adoptive transfer of IL-4/IL-13-polarized M2 macrophages in SCID mice with adriamycin nephropathy was shown to improve kidney function potentially by inhibiting inflammatory macrophage infiltration (Wang et al. 2007). Transfer of in vitro polarized M2 macrophages also suppressed development of interstitial fibrosis in murine diabetes-induced renal injury (Zheng et al. 2011). Further, IL-25-mediated M2 macrophage polarization in vivo reduced proteinuria and glomerulosclerosis in adriamycininduced CKD (Cao et al. 2011). During IRI, deletion of IL-4 and IL-13 (Zhang et al. 2017a, b) or proximal tubulederived CSF-1 (Wang et al. 2015) resulted in reduced M2 polarization and inhibited recovery from acute kidney injury.

Regarding M2 macrophage-mediated iTreg induction in kidney disease, there is one study describing that in kidney transplantation, preoperative transfer of donorderived regulatory macrophages (Mregs), which have been polarized in vitro in presence of M-CSF and IFNy, resulted in increased numbers of circulating TIGIT $^{+}$ Foxp $3^{+}$Tregs in living-donor kidney transplant recipients. The authors suggested a feed-forward mechanism by which Mregs might promote allograft survival by iTreg induction (Riquelme et al. 2018). Moreover, adoptively transferred IL-10/TGF $\beta$-polarized M2 macrophages were shown to attenuate renal inflammation and decline in kidney function in murine adriamycin nephropathy. The M2 macrophages promoted differentiation of iTregs from naïve $\mathrm{CD} 4^{+} \mathrm{T}$ cells in vitro and increased the number of Tregs in draining lymph nodes in vivo (Cao et al. 2010). In a following study, M2 macrophages were subdivided into IL-4/IL-13-polarized M2a and IL-10/TGF $\beta$-polarized M2c macrophage subsets. After adoptive transfer, both subsets ameliorated renal inflammation and injury in adriamycin nephropathy. However, M2c macrophages showed a stronger immunosuppressive capacity and more effectively reduced proteinuria and renal fibrosis. This was attributed to the ability of M2c but not M2a macrophages to promote iTreg differentiation in vitro and to enhance Treg numbers in draining lymph nodes in vivo (Lu et al. 2013).

\section{Regulation of renal inflammation by innate immune cells}

\section{Type 2 innate lymphoid cells}

Type 2 innate lymphoid cells (ILC2) are effector cells of the innate immune response, which become rapidly activated during infection and inflammation, e.g., by release of alarmin IL-33 from damaged cells. ILC2 express the transcription factor GATA3 and produce IL-5 and IL-13 as well as the epidermal growth factor AREG. ILC2 are major players in allergy and asthma but also mediate tissue injury, fibrosis and regeneration in other organs (Klose and Artis 2016; Ochel et al. 2019).

A recent study showed that in MRL/lpr mice, progression of lupus nephritis was accompanied by a continuous reduction of ILC2 numbers in the inflamed kidney, which was most likely mediated by the chronic Th1 immune response. Interestingly, treatment of MRL/lpr mice with the ILC2-activating cytokine IL-33 restored renal ILC2 numbers and attenuated lupus nephritis (Düster et al. 2018). However, mechanisms by which renal ILC2 mediate their immunosuppressive function in SLE remain to be determined. One might speculate that IL-33-activated ILC2 release AREG, which was shown to maintain and enhance Treg function during inflammation (Zaiss et al. 2013). Like IL-33, the hybrid cytokine IL-233 also expanded ILC2 in the kidney (Stremska et al. 2017). ILC2 typically expresses not only ST2 but also CD25 (Roediger et al. 2013). Interestingly, adoptive transfer of ILC2, expanded in vitro by IL-233 (Stremska et al. 2017) or IL-2/IL-7/IL-33 (Cao et al. 2018), protected mice against renal IRI. Moreover, administration of recombinant IL-33 to mice several days before induction of IRI expanded ILC2, Tregs and anti-inflammatory M2 macrophages in the kidney and prevented renal injury. The protective effect of IL-33 was mediated by ILC2 and M2 macrophages but not by Tregs. Interestingly, IL-33 and ILC2 were also protective upon curative treatment administered $24 \mathrm{~h}$ after IRI induction (Cao et al. 2018). Along the same line, short-term IL-33 treatment was demonstrated to expand ILC2 and attenuated renal inflammation and glomerulosclerosis in adriamycin nephropathy (Riedel et al. 2017). The functional role of ILC2 for the reno-protective effect was shown in ILC-deficient $\mathrm{Rag}^{-/-} \times \mathrm{Il}_{2} \mathrm{rcg}^{-/-}$mice, where IL-33 administration failed to reduce adriamycininduced inflammation and glomerulosclerosis. Moreover, expression of macrophage markers linked with a regulatory M2 phenotype was shown in IL-33-treated nephritic wildtype mice, which was associated with renal expression of IL-5 and IL-13, a cytokine that induces polarization of M2 macrophages (Gordon 2003). IL-5 instead is a strong activator of eosinophils. Interestingly, IL-33 treatment in the absence of eosinophils, i.e., in eosinophil-deficient $\Delta$ dblGATA mice, failed to protect from adriamycin nephropathy despite an unaltered expansion of ILC2 (Riedel et al. 2017). Hence, IL-33-activated ILC2 and their mediators seem to activate a network of immune regulatory and tissue repair cells such as Tregs, M2 macrophages and eosinophils that dampen organ inflammation and favor tissue regeneration (Fig. 3). However, since IL-33 was shown to play a critical role in the pathogenesis of renal IRI (Liang et al. 2017; Ferhat et al. 2018) and drug-induced AKI (Akcay et al. 2011), therapeutic safety of this cytokine should be carefully evaluated.

In a recent paper, it was demonstrated that administration of the IL-2/anti-IL-2 mAb complex expanded regulatory ILC2 


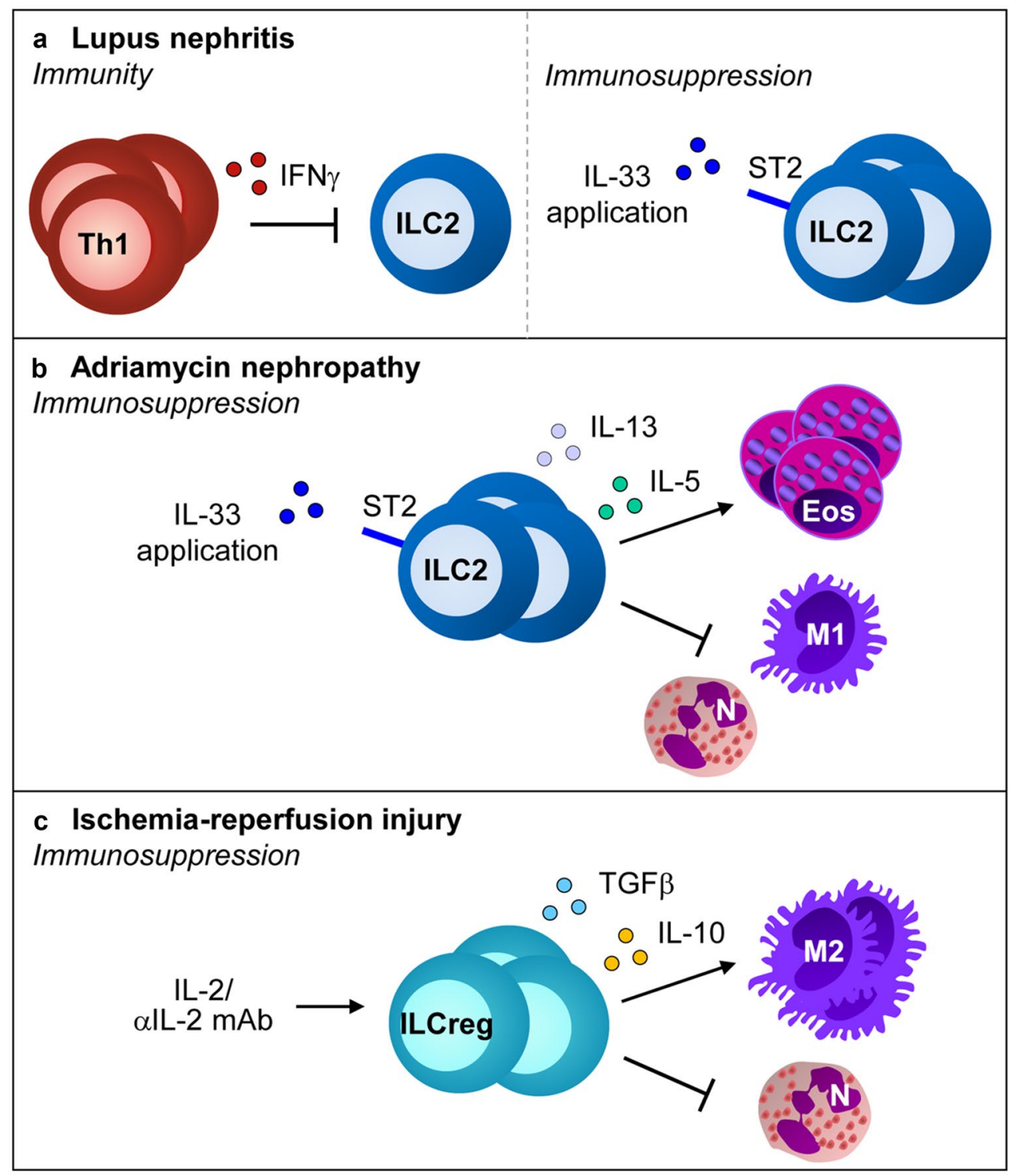

Fig. 3 Activation and function of ILC2 in kidney disease. Application of IL-33 induces activation and expansion of renal ILC2 while IFN $\gamma$ has an inhibitory effect. Activated ILC2 exert an immunosuppressive function in adriamycin nephropathy through inhibition of M1 macrophages and neutrophils as well as activation and recruitment of

(ILCregs). These cells showed immunosuppressive effects on pro-inflammatory ILC1 and macrophages in vitro via production of IL-10 and TGF $\beta$. Likewise, adoptive transfer of ILCregs prevented renal IRI along with a reduction of neutrophil infiltration and induction of M2 macrophages. In addition, the IL-2/anti-IL-2 mAb complex prevented renal IRI in $\mathrm{Rag}^{-/-}$mice, which was probably due to induction of ILCregs (Cao et al. 2020). These observations may provide a possible explanation of the protective effect of transferred Tregs against renal IRI in $\mathrm{Ragl}^{-/-}$mice that still harbor ILC2 (Fig. 3). As T cells directly interact with ILC2 either by cytokine production or TCR-MHCII interactions (Gasteiger and Rudensky 2014; eosinophils. In IRI, treatment with the IL-2/anti-IL-2 mAb complex induces ILCreg, which promote M2 macrophage polarisation by production of TGF $\beta$ and IL-10. N: neutrophils, M1: M1 macrophages, Eos: eosinophils, M2: M2 macrophages

Steinmann et al. 2020), Tregs might have polarized and activated ILCregs to suppress the pro-inflammatory innate immune response in $\mathrm{Rag}^{-/-}$mice, which is raised upon renal IRI.

\section{Mast cells}

Mast cells (MC) are known to promote tissue injury, in particular in the context of allergic disease. However, MC have been shown to accumulate in renal interstitium of patients with various types of GN (Tóth et al. 1999; Ehara and Shigematsu 1998) and were found to play a pathogenic role in the mouse model of NTN (Timoshanko et al. 2006). In contrast, in accelerated 
NTN, MCs were demonstrated to control the immune response. In MC-deficient mice, an increase of infiltrating interstitial macrophages, $\mathrm{CD}^{+}$and $\mathrm{CD}^{+} \mathrm{T}$ cells compared to MC-proficient mice was observed in NTN and aggravation of inflammation correlated with increased proteinuria and glomerular damage (Hochegger et al. 2005). A follow-up study showed that Treg-derived IL-9, a MC growth and activation factor, induced recruitment of MC into renal draining lymph nodes thereby suppressing immune activation in the kidney during NTN (Eller et al. 2011). A similar immune inhibitory mechanism has been described in a model of transplantation tolerance, where Treg-derived IL-9 recruited and activated MC in tolerant tissue (Lu et al. 2006). However, the subtypes of MC that mediate either inflammation or immune regulation in the kidney have not been identified yet. Recently, a mechanism for MC-mediated immunosuppression has been described, in which MC produce AREG that binds to the EGF receptor expressed by Tregs under inflammatory conditions thereby enhancing their immunosuppressive capacity in vitro and in vivo (Zaiss et al. 2013). Hence, it seems that Tregs and MC amplify their immunosuppressive function by an IL-9- and AREGdependent autocrine loop. Moreover, in ANCA-associated antiMPO GN, MCs were shown to ameliorate disease pathology by IL-10 production that ensured Treg recruitment and immunosuppressive function (Gan et al. 2012).

\section{Proximal tubular epithelial cells}

Besides professional APCs like DCs and macrophages, other MHCII-expressing cell populations have been identified, which also exert the capacity to stimulate $\mathrm{CD} 4^{+} \mathrm{T}$ cells and therefore, are termed non-professional APCs. Particularly epithelial and endothelial cells have been suggested to play a role in the initiation and regulation of $\mathrm{CD} 4^{+} \mathrm{T}$ cell responses during inflammation (Kambayashi and Laufer 2014). In the kidney, several studies have demonstrated low MHCII expression by proximal tubular epithelial cells (PTECs) of healthy humans (Gastl et al. 1996) and naïve mice (Hagerty and Allen 1992), which was up-regulated in renal cell carcinoma patients (Gastl et al. 1996) as well as murine lupus nephritis (Wuthrich et al. 1989), graft-versus-host disease (Sinclair et al. 1984) and kidney transplants (Kouwenhoven et al. 2001). Moreover, PTECs were shown to process and present soluble antigens, thereby inducing activation of $\mathrm{CD}^{+}{ }^{+} \mathrm{T}$ cell hybridoma (Hagerty and Allen 1992). In comparative analysis, we have recently demonstrated that particularly PTECs and not distal tubular epithelial cells express molecules linked with APC function including MHCII, the co-stimulatory molecules CD80/CD86 and the MHCII invariant chain CD74 in naïve and nephritic NTN mice. In patients with ANCA-associated GN, CD86 expression was also restricted to proximal tubules while expression of MHCII and CD74 was detected in both proximal and distal tubules (Breda et al. 2019).
That non-professional APCs can exert immunomodulatory functions beside professional APCs has been particularly demonstrated in the liver. Here, liver sinusoidal endothelial cells (LSECs) were shown to promote Treg induction (Kruse et al. 2009; Carambia et al. 2014), inhibit inflammatory cytokine production (Carambia et al. 2013), induce T-cell anergy (Diehl et al. 2008) and tolerize professional APCs (Schildberg et al. 2008), thereby contributing to hepatic tolerance induction. In contrast, PTECs did not favor induction of Tregs (Breda et al. 2019) and instead were found to induce antigen-specific $\mathrm{CD} 4^{+} \mathrm{T}$ cell activation and pro-inflammatory cytokine expression in vitro (Breda et al. 2019; Waeckerle-Men et al. 2007). However, compared to professional DCs, PTECs induced a rather weak activation of $\mathrm{CD}^{+} \mathrm{T}$ cells probably due to low expression levels of MHCII (Breda et al. 2019). In addition, PTECs were shown to regulate activation of $\mathrm{T}$ cells by the co-inhibitory molecule PD-L1. Several studies have reported induction of PD-L1 expression in PTECs by the cytokine IFN $\gamma$ in vitro, which resulted in suppression of T-cell activation and inflammatory cytokine expression (Waeckerle-Men et al. 2007; Starke et al. 2010; Wilkinson et al. 2011). Thus, PTECs can induce proinflammatory $\mathrm{CD}^{+} \mathrm{T}$ cell activation that might be regulated through inflammation-induced induction of epithelial PD-L1 expression. However, all data regarding PTEC-mediated T cell activation were derived from in vitro experiments and it still remains unclear whether PTECs exert immunomodulatory function in vivo in the course of GN and what effect epithelial cell-mediated T-cell activation has for disease pathology.

\section{Conclusion and therapeutic outlook}

Autoimmune diseases result from a breakdown of tolerance against self-antigens. Antigen-specific nTregs selected in the thymus represent the major cell population that prevents systemic and organ-specific autoimmunity. Contrary, reduction of cell number, stability, or immunosuppressive function of Tregs can evoke autoimmunity. In the kidney, autoimmune GNs have been associated with aberrant Treg responses displaying different mechanisms of dysregulation. For example, the number of Tregs is reduced in patients with lupus nephritis due to impaired T cell-mediated IL-2 production. Thus, therapeutic expansion of endogenous Tregs using low-dose IL-2 has been successfully established. However, this might not be a treatment option for other autoimmune kidney diseases. Therefore, different strategies to more effectively expand endogenous Tregs are currently investigated in animal models of GN including treatment with IL-2/anti-IL-2 mAb complexes, IL-2 and IL-33 or IL-233. These treatment regimens have the obvious advantage to locally expand and stabilize self-reactive Tregs. Interestingly, these treatment strategies also prevent 
acute and chronic nephrotoxicity, which could be due to immunosuppressive bystander activities of Tregs or Tregdependent expansion of ILC2, which seem to be suppressive themselves via activation of a network of immune regulatory cells in the kidney that include Tregs and M2 macrophages.

Cellular Treg therapies, where patient-derived Tregs are expanded in vitro by different protocols and re-injected to the patients, have been extensively studied in clinical trials for the control of allo-reactive immune responses in transplant rejection and self-reactive immunity in autoimmune diseases such as type 1 diabetes, Crohn's disease and autoimmune hepatitis. These trials use autologous polyclonally expanded Tregs mostly isolated from peripheral blood. The expansion protocols involve un-specific TCR stimulation in the presence of IL-2 and sometimes TGF $\beta$ and all-trans retinoic acid. Ongoing clinical trials show safety and feasibility of Treg infusion; however, long-term stability of the administered Tregs as well as their trafficking into the affected organ need further investigation (Romano et al. 2019). In the kidney, clinical trials are currently investigating the therapeutic potential of cellular Treg therapies in kidney transplantation (Romano et al. 2019). Based on the findings in mouse models of autoimmune GN demonstrating the necessity of a functional Treg compartment for disease control, cellular Treg therapies should also be addressed in GN patients.

Besides Treg-based therapy, application of tolerogenic DCs is currently being tested in clinical trials for the treatment of allograft rejection and autoimmune diseases such as type 1 diabetes, rheumatoid arthritis, inflammatory bowel disease and multiple sclerosis since these cells not only induce anergy and apoptosis in effector $\mathrm{T}$ cells but also mediate iTreg induction in vivo (Obregon et al. 2017; Cauwels et al. 2020). In kidney disease, the protective potential of donor-derived tolerogenic DCs and also Mregs is being explored in renal transplant patients (Obregon et al. 2017; Amodio et al. 2019; Cauwels et al. 2020). Hence, experience gained in this clinical setup might encourage trials using cell-based immunosuppressive therapy as a treatment option for renal autoimmune diseases.

Funding Open Access funding enabled and organized by Projekt DEAL. This work was supported by the Deutsche Forschungsgemeinschaft (DFG): SFB 1192 project A2 granted to K.N. and G.T.

\section{Compliance with ethical standards}

Conflict of interest The authors declare that they have no conflict of interest.

Open Access This article is licensed under a Creative Commons Attribution 4.0 International License, which permits use, sharing, adaptation, distribution and reproduction in any medium or format, as long as you give appropriate credit to the original author(s) and the source, provide a link to the Creative Commons licence and indicate if changes were made. The images or other third party material in this article are included in the article's Creative Commons licence, unless indicated otherwise in a credit line to the material. If material is not included in the article's Creative Commons licence and your intended use is not permitted by statutory regulation or exceeds the permitted use, you will need to obtain permission directly from the copyright holder. To view a copy of this licence, visit http://creativecommons. org/licenses/by/4.0/.

\section{References}

Akbari O, DeKruyff RH, Umetsu DT (2001) Pulmonary dendritic cells producing IL-10 mediate tolerance induced by respiratory exposure to antigen. Nat Immunol 2:725-731

Akcay A, Nguyen Q, He Z, Turkmen K, Won Lee D, Hernando AA, Altmann C, Toker A, Pacic A, Ljubanovic DG, Jani A, Faubel S, Edelstein CL (2011) IL-33 exacerbates acute kidney injury. J Am Soc Nephrol 22:2057-2067

Alcocer-Varela J, Alarcon-Segovia D (1982) Decreased production of and response to interleukin-2 by cultured lymphocytes from patients with systemic lupus erythematosus. J Clin Invest 69:1388-1392

Amodio G, Cichy J, Conde P, Matteoli G, Moreau A, Ochando J, Oral BH, Pekarova M, Ryan EJ, Roth J, Sohrabi Y, Cuturi MC, Gregori S (2019) Role of myeloid regulatory cells (MRCs) in maintaining tissue homeostasis and promoting tolerance in autoimmunity, inflammatory disease and transplantation. Cancer Immunol Immunother 68:661-672

Anders HJ (2016) Of Inflammasomes and alarmins: IL-1 $\beta$ and IL- $1 \alpha$ in kidney disease. J Am Soc Nephrol 27:2564-2575

Apostolou I, von Boehmer H (2004) In vivo instruction of suppressor commitment in naive T cells. J Exp Med 199:1401-1408

Bagavant H, Fu SM (2009) Pathogenesis of kidney disease in systemic lupus erythematosus. Curr Opin Rheumatol 21:489-494

Beriou G, Costantino CM, Ashley CW, Yang L, Kuchroo VK, Baecher-Allan C, Hafler DA (2009) IL-17-producing human peripheral regulatory $\mathrm{T}$ cells retain suppressive function. Blood 113:4240-4249

Breda PC, Wiech T, Meyer-Schwesinger C, Grahammer F, Huber T, Panzer U, Tiegs G, Neumann K (2019) Renal proximal tubular epithelial cells exert immunomodulatory function by driving inflammatory CD4+ T cell responses. Am J Physiol - Ren Physiol 317:F77-F89

Burne MJ, Daniels F, El Ghandour A, Mauiyyedi S, Colvin RB, O'Donnell MP, Rabb H (2001) Identification of the CD4+ T cell as a major pathogenic factor in ischemic acute renal failure. J Clin Invest 108:1283-1290

Cairns LS, Phelps RG, Bowie L, Hall AM, Saweirs WW, Rees AJ, Barker RN (2003) The fine specificity and cytokine profile of T-helper cells responsive to the $\alpha 3$ chain of type IV collagen in Goodpasture's disease. J Am Soc Nephrol 14:2801-2812

Cao Q, Wang R, Wang Y, Niu Z, Chen T, Wang C, Jin L, Huang Q, Li Q, Wang XM, Azmi F, Lee VWS, Wang YM, Zheng G, Alexander SI, Harris DCH (2020) Regulatory innate lymphoid cells suppress innate immunity and reduce renal ischemia/reperfusion injury. Kidney Int 97:130-142

Cao Q, Wang Y, Niu Z, Wang C, Wang R, Zhang Z, Chen T, Wang XM, Li Q, Lee VWS, Huang Q, Tan J, Guo M, Wang YM, Zheng G, Yu D, Alexander SI, Wang H, Harris DCH (2018) Potentiating tissueresident type 2 innate lymphoid cells by IL-33 to prevent renal ischemia-reperfusion injury. J Am Soc Nephrol 29:961-976

Cao Q, Wang Y, Zheng D, Sun Y, Wang Y, Lee VW, Zheng G, Tan TK, Ince J, Alexander SI, Harris DC (2010) IL-10/TGF-betamodified macrophages induce regulatory $\mathrm{T}$ cells and protect against adriamycin nephrosis. J Am Soc Nephrol 21:933-942

Cao Q, Wang C, Zheng D, Wang Y, Lee VW, Wang YM, Zheng G, Tan TK, Yu D, Alexander SI, Harris DC, Wang Y (2011) IL-25 induces M2 
macrophages and reduces renal injury in proteinuric kidney disease. J Am Soc Nephrol 22:1229-1239

Carambia A, Frenzel C, Bruns OT, Schwinge D, Reimer R, Hohenberg H, Huber S, Tiegs G, Schramm C, Lohse AW, Herkel J (2013) Inhibition of inflammatory CD4 T cell activity by murine liver sinusoidal endothelial cells. J Hepatol 58:112-118

Carambia A, Freund B, Schwinge D, Heine M, Laschtowitz A, Huber S, Wraith DC, Korn T, Schramm C, Lohse AW, Heeren J, Herkel $\mathrm{J}$ (2014) TGF- $\beta$-dependent induction of CD4+CD25+Foxp3+ Tregs by liver sinusoidal endothelial cells. J Hepatol 61:594-599

Cauwels A, Tavernier J (2020) Tolerizing Strategies for the treatment of autoimmune diseases: From ex vivo to in vivo strategies. Front Immunol 11:674

Chang J, Eggenhuizen P, O’Sullivan KM, Alikhan MA, Holdsworth SR, Ooi JD, Kitching AR (2017) CD8 ${ }^{+}$T cells effect glomerular injury in experimental anti-myeloperoxidase GN. J Am Soc 28:47-55

Chen L, Flies DB (2013) Molecular mechanisms of $\mathrm{T}$ cell co-stimulation and co-inhibition. Nat Rev Immunol 13:227-242

Chen Z, Barbi J, Bu S, Yang HY, Li Z, Gao Y, Jinasena D, Fu J, Lin F, Chen C, Zhang J, Yu N, Li X, Shan Z, Nie J, Gao Z, Tian H, Li Y, Yao Z, Zheng Y, Park BV, Pan Z, Zhang J, Dang E, Li Z, Wang H, Luo W, Li L, Semenza GL, Zheng SG, Loser K, Tsun A, Greene MI, Pardoll DM, Pan F, Li B (2013) The ubiquitin ligase stub1 negatively modulates regulatory $\mathrm{T}$ cell suppressive activity by promoting degradation of the transcription factor Foxp3. Immunity 39:272-285

Coombes JL, Siddiqui KR, Arancibia-Cárcamo CV, Hall J, Sun CM, Belkaid Y, Powrie F (2007) A functionally specialized population of mucosal CD103+ DCs induces Foxp3+ regulatory T cells via a TGF-beta and retinoic acid-dependent mechanism. J Exp Med 204:1757-1764

Crispín JC, Tsokos GC (2010) Interleukin-17-producing T cells in lupus. Curr Opin Rheumatol 22:499-503

D'Cruz LM, Klein L (2005) Development and function of agonistinduced CD25+Foxp3+ regulatory T cells in the absence of interleukin 2 signaling. Nat Immunol 6:1152-1159

Dai H, He F, Tsokos GC, Kyttaris VC (2017) IL-23 limits the production of IL-2 and promotes autoimmunity in lupus. J Immunol 199:903-910

Dauphinée MJ, Kipper SB, Wofsy D, Talal N (1981) Interleukin 2 deficiency is a common feature of autoimmune mice. J Immunol 27:2483-2487

de Oliveira BM, Carvalho JL, Saldanha-Araujo F (2016) Adenosine production: A common path for mesenchymal stem-cell and regulatory T-cell-mediated immunosuppression. Purinergic Signal 12:595-609

Diefenhardt P, Nosko A, Kluger MA, Richter JV, Wegscheid C, Kobayashi Y, Tiegs G, Huber S, Flavell RA, Stahl RAK, Steinmetz OM (2018) IL-10 receptor signaling empowers regulatory T cells to control Th17 responses and protect from GN. J Am Soc Nephrol 29:1825-1837

Diehl L, Schurich A, Grochtmann R, Hegenbarth S, Chen L, Knolle PA (2008) Tolerogenic maturation of liver sinusoidal endothelial cells promotes $\mathrm{B} 7$-homolog 1-dependent $\mathrm{CD} 8+\mathrm{T}$ cell tolerance. Hepatology 47:296-305

do Valle Duraes F, Lafont A, Beibel M, Martin K, Darribat K, Cuttat R, Waldt A, Naumann U, Wieczorek G, Gaulis S, Pfister S, Mertz KD, Li J, Roma G, Warncke M, (2020) Immune cell landscaping reveals a protective role for regulatory $\mathrm{T}$ cells during kidney injury and fibrosis. JCI Insight 5:e130651

Domogalla MP, Rostan PV, Raker VK, Steinbrink K (2017) Tolerance through education: How tolerogenic dendritic cells shape immunity. Front Immunol 8:1764

Düster M, Becker M, Gnirck AC, Wunderlich M, Panzer U, Turner JE (2018) T cell-derived IFN- $\gamma$ downregulates protective group 2 innate lymphoid cells in murine lupus erythematosus. Eur $\mathbf{J}$ Immunol 48:1364-1375

Ehara T, Shigematsu H (1998) Contribution of mast cells to the tubulointerstitial lesions in IgA nephritis. Kidney Int 54:1675-1683
Eller K, Wolf D, Huber JM, Metz M, Mayer G, McKenzie ANJ, Mauer M, Rosenkranz AR, Wolf AM (2011) IL-9 production by regulatory $\mathrm{T}$ cells recruits mast cells that are essential for regulatory $\mathrm{T}$ cellinduced immune suppression. J Immunol 186:83-91

Evers BD, Engel DR, Böhner AM, Tittel AP, Krause TA, Heuser C, Garbi N, Kastenmüller W, Mack M, Tiegs G, Panzer U, Boor P, LudwigPortugall I, Kurts C (2016) CD103+ kidney dendritic cells protect against crescentic GN by maintaining IL-10-producing regulatory T cells. J Am Soc Nephrol 27:3368-3382

Erhardt A, Wegscheid C, Claass B, Carambia A, Herkel J, Mittrücker HW, Panzer U, Tiegs G (2011) CXCR3 deficiency exacerbates liver disease and abrogates tolerance in a mouse model of immune-mediated hepatitis. J Immunol 186:5284-5293

Ferhat M, Robin A, Giraud S, Sena S, Goujon JM, Touchard G, Hauet T, Girard JP, Gombert JM, Herbelin A, Thierry A (2018) Endogenous IL-33 contributes to kidney ischemia-reperfusion injury as an alarmin. J Am Soc Nephrol 29:1272-1288

Ferreira GB, Gysemans CA, Demengeot J, da Cunha JP, Vanherwegen AS, Overbergh L, Van Belle TL, Pauwels F, Verstuyf A, Korf H, Mathieu C (2014) 1,25-Dihydroxyvitamin D3 promotes tolerogenic dendritic cells with functional migratory properties in NOD mice. J Immunol 192:4210-4220

Floess S, Freyer J, Siewert C, Baron U, Olek S, Polansky J, Schlawe K, Chang HD, Bopp T, Schmitt E, Klein-Hessling S, Serfling E, Hamann A, Huehn J (2007) Epigenetic control of the foxp3 locus in regulatory T cells. PLoS Biol 5:e38

Fontenot JD, Rasmussen JP, Gavin MA, Rudensky AY (2005) A function for interleukin 2 in Foxp3-expressing regulatory T cells. Nat Immunol 6:1142-1151

Francisco LM, Salinas VH, Brown KE, Vanguri VK, Freeman GJ, Kuchroo VK, Sharpe AH (2009) PD-L1 regulates the development, maintenance, and function of induced regulatory T cells. J Exp Med 206:3015-3029

Free ME, Bunch DO, McGregor JA, Jones BE, Berg EA, Hogan SL, Hu Y, Preston GA, Jennette JC, Falk RJ (2013) Patients with antineutrophil cytoplasmic antibody-associated vasculitis have defective treg cell function exacerbated by the presence of a suppression-resistant effector cell population. Arthritis Rheum 65:1922-1933

Freeman GJ, Long AJ, Iwai Y, Bourque K, Chernova T, Nishimura H, Fitz LJ, Malenkovich N, Okazaki T, Byrne MC, Horton HF, Fouser L, Carter L, Ling V, Bowman MR, Carreno BM, Collins M, Wood CR, Honjo T (2000) Engagement of the Pd-1 immunoinhibitory receptor by a novel $\mathrm{B} 7$ family member leads to negative regulation of lymphocyte activation. J Exp Med 192:1027-1034

Gan PY, Holdsworth SR, Kitching AR, Ooi JD (2013) Myeloperoxidase (MPO)-specific CD4+ T cells contribute to MPO-anti-neutrophil cytoplasmic antibody (ANCA) associated glomerulonephritis. Cell Immunol 282:21-27

Gan PY, Summers SA, Ooi JD, O'Sullivan KM, Tan DS, Muljadi RC, Odobasic D, Kitching AR, Holdsworth SR (2012) Mast cells contribute to peripheral tolerance and attenuate autoimmune vasculitis. J Am Soc Nephrol 23:1955-1966

Gasteiger G, Rudensky AY (2014) Interactions between innate and adaptive lymphocytes. Nat Rev Immunol 14:631-639

Gastl G, Ebert T, Finstad CL, Sheinfeld J, Gomahr A, Aulitzky W, Bander NH (1996) Major histocompatibility complex class I and class II expression in renal cell carcinoma and modulation by interferon gamma. J Urol 155:361-367

Gordon S (2003) Alternative activation of macrophages. Nat Rev Immunol 3:23-35

Gordon S, Martinez FO (2010) Alternative activation of macrophages: mechanism and functions. Immunity 32:593-604

Gutierrez-Ramos JC, Andreu JL, Revilla Y, Viñuela E, Martinez C (1990) Recovery from autoimmunity of MRL/lpr mice after 
infection with an interleukin-2/vaccinia recombinant virus. Nature 346:271-274

Hagerty DT, Allen PM (1992) Processing and presentation of self and foreign antigens by the renal proximal tubule. J Immunol 148:2324-2330

He J, Zhang X, Wei Y, Sun X, Chen Y, Deng J, Jin Y, Gan Y, Hu X, Jia R, Xu C, Hou Z, Leong YA, Zhu L, Feng J, An Y, Jia Y, Li C, Liu X, Ye H, Ren L, Li R, Yao H, Li Y, Chen S, Zhang X, Su Y, Guo J, Shen N, Morand EF, Li Z (2016) Low-dose interleukin-2 treatment selectively modulates CD4+ T cell subsets in patients with systemic lupus erythematosus. Nat Med 22:991-993

Hochegger K, Siebenhaar F, Vielhauer V, Heininger D, Mayadas TN, Mayer G, Maurer M, Rosenkranz AR (2005) Role of mast cells in experimental anti-glomerular basement membrane glomerulonephritis. Eur J Immunol 35:3074-3082

Hochheiser K, Engel DR, Hammerich L, Heymann F, Knolle PA, Panzer U, Kurts C (2011) Kidney dendritic cells become pathogenic during crescentic glomerulonephritis with proteinuria. J Am Soc Nephrol 22:306-316

Huang XR, Holdsworth SR, Tipping PG (1994) Evidence for delayedtype hypersensitivity mechanisms in glomerular crescent formation. Kidney Int 46:69-78

Humrich JY, Morbach H, Undeutsch R, Enghard P, Rosenberger S, Weigert O, Kloke L, Heimann J, Gaber T, Brandenburg S, Scheffold A, Huehn J, Radbruch A, Burmester GR, Riemekasten G (2010) Homeostatic imbalance of regulatory and effector T cells due to IL-2 deprivation amplifies murine lupus. Proc Natl Acad Sci U S A 107:204-209

Hünemörder S, Treder J, Ahrens S, Schumacher V, Paust HJ, Menter T, Matthys P, Kamradt T, Meyer-Schwesinger C, Panzer U, Hopfer H, Mittrücker HW (2015) TH1 and TH17 cells promote crescent formation in experimental autoimmune glomerulonephritis. J Pathol 237:62-71

Hutton HL, Ooi JD, Holdsworth SR, Kitching AR (2016) The NLRP3 inflammasome in kidney disease and autoimmunity. Nephrology 21:736-744

Irla M, Küpfer N, Suter T, Lissilaa R, Benkhoucha M, Skupsky J, Lalive PH, Fontana A, Reith W, Hugues S (2010) MHC class II-restricted antigen presentation by plasmacytoid dendritic cells inhibits $\mathrm{T}$ cellmediated autoimmunity. J Exp Med 207:1891-1905

Iruretagoyena MI, Sepúlveda SE, Lezana JP, Hermoso M, Bronfman M, Gutiérrez MA, Jacobelli SH, Kalergis AM (2006) Inhibition of nuclear factor-kappa B enhances the capacity of immature dendritic cells to induce antigen-specific tolerance in experimental autoimmune encephalomyelitis. J Pharmacol Exp Ther 31:59-67

Jang HR, Rabb H (2015) Immune cells in experimental acute kidney injury. Nat Rev Nephrol 11:88-101

Jaworska K, Ratajczak J, Huang L, Whalen K, Yang M, Stevens BK, Kinsey GR (2015) Both PD-1 ligands protect the kidney from ischemia reperfusion injury. J Immunol 194:325-333

Jin LW, Ye HY, Xu XY, Zheng Y, Chen Y (2018) MiR-133a/133b inhibits Treg differentiation in $\operatorname{IgA}$ nephropathy through targeting FOXP3. Biomed Pharmacother 101:195-200

Josefowicz SZ, Lu L-F, Rudensky AY (2012) Regulatory T Cells: Mechanisms of Differentiation and Function. Annu Rev Immunol 30:531-564

Kambayashi T, Laufer TM (2014) Atypical MHC class II-expressing antigen-presenting cells: Can anything replace a dendritic cell? Nat Rev Immunol 14:719-730

Kasagi S, Kawano S, Okazaki T, Honjo T, Morinobu A, Hatachi S, Shimatani K, Tanaka Y, Minato N, Kumagai S (2010) Anti-Programmed cell death 1 antibody reduces CD4 + PD-1 + T cells and relieves the lupus-like nephritis of NZB/W F1 mice. J Immunol 184:2337-2347

Keir ME, Butte MJ, Freeman GJ, Sharpe AH (2008) PD-1 and its ligands in tolerance and immunity. Annu Rev Immunol 26:677-704
Keir ME, Latchman YE, Freeman GJ, Sharpe AH (2005) Programmed death-1 (PD-1):PD-ligand 1 interactions inhibit TCR-mediated positive selection of thymocytes. J Immunol 175:7372-7379

Kim MG, Koo TY, Yan JJ, Lee E, Han KH, Jeong JC, Ro H, Kim BS, Jo SK, Oh KH, Surh CD, Ahn C, Yang J (2013) IL-2/anti-IL-2 complex attenuates renal ischemia-reperfusion injury through expansion of regulatory T cells. J Am Soc Nephrol 24:1529-1536

Kinsey GR, Huang L, Jaworska K, Khutsishvili K, Becker DA, Ye H, Lobo PI, Okusa MD (2012) Autocrine adenosine signaling promotes regulatory $\mathrm{T}$ cell-mediated renal protection. J Am Soc Nephrol 23:1528-1537

Kinsey GR, Sharma R, Huang L, Li L, Vergis AL, Ye H, Ju ST, Okusa MD (2009) Regulatory T cells suppress innate immunity in kidney ischemia-reperfusion injury. J Am Soc Nephrol 20:1744-1753

Kitching AR, Holdsworth SR, Tipping PG (1999) IFN- $\gamma$ mediates crescent formation and cell-mediated immune injury in murine glomerulonephritis. J Am Soc Nephrol 10:752-759

Kitching AR, Tipping PG, Holdsworth SR (1999) IL-12 directs severe renal injury, crescent formation and Th1 responses in murine glomerulonephritis. Eur J Immunol 29:1-10

Kitching AR, Tipping PG, Timoshanko JR, Holdsworth SR (2000) Endogenous interleukin-10 regulates Th1 responses that induce crescentic glomerulonephritis. Kidney Int 57:518-525

Klinge S, Yan K, Reimers D, Brede KM, Schmid J, Paust HJ, Krebs CF, Panzer U, Hopfer H, Mittrücker HW (2019) Role of regulatory $\mathrm{T}$ cells in experimental autoimmune glomerulonephritis. Am J Physiol - Ren Physiol 316:F572-F581

Klose CSN, Artis D (2016) Innate lymphoid cells as regulators of immunity, inflammation and tissue homeostasis. Nat Immunol 17:765-774

Kluger MA, Luig M, Wegscheid C, Goerke B, Paust HJ, Brix SR, Yan I, Mittrücker HW, Hagl B, Renner ED, Tiegs G, Wiech T, Stahl RA, Panzer U, Steinmetz OM (2014) Stat3 programs Th17-specific regulatory T cells to control GN. J Am Soc Nephrol 25:1291-1302

Kluger MA, Melderis S, Nosko A, Goerke B, Luig M, Meyer MC, Turner JE, Meyer-Schwesinger C, Wegscheid C, Tiegs G, Stahl RA, Panzer U, Steinmetz OM (2016) Treg 17 cells are programmed by Stat 3 to suppress Th17 responses in systemic lupus. Kidney Int 89:158-166

Kluger MA, Meyer MC, Nosko A, Goerke B, Luig M, Wegscheid C, Tiegs G, Stahl RA, Panzer U, Steinmetz OM (2016) RORgt+Foxp3+ cells are an independent bifunctional regulatory $t$ cell lineage and mediate crescentic GN. J Am Soc Nephrol 27:454-465

Kluger MA, Ostmann A, Luig M, Meyer MC, Goerke B, Paust HJ, Meyer-Schwesinger C, Stahl RA, Panzer U, Tiegs G, Steinmetz OM (2014) B-cell-derived IL-10 does not vitally contribute to the clinical course of glomerulonephritis. Eur J Immunol 44:683-693

Koch MA, Tucker-Heard G, Perdue NR, Killebrew JR, Urdahl KB, Campbell DJ (2009) The transcription factor T-bet controls regulatory $\mathrm{T}$ cell homeostasis and function during type 1 inflammation. Nat Immunol 10:595-602

Koo TY, Lee JG, Yan JJ, Jang JY, Ju KD, Han M, Oh KH, Ahn C, Yang J (2017) The P2X7 receptor antagonist, oxidized adenosine triphosphate, ameliorates renal ischemia-reperfusion injury by expansion of regulatory T cells. Kidney Int 92:415-431

Kouwenhoven EA, de Bruin RW, Heemann UW, Marquet RL, IJzermans $\mathrm{JN}$, (2001) Cold ischemia augments allogeneic-mediated injury in rat kidney allografts. Kidney Int 59:1142-1148

Krebs CF, Steinmetz OM (2016) CD4+ T cell fate in glomerulonephritis: A tale of Th1, Th17, and novel Treg subtypes. Mediators Inflamm 2016:5393894

Kretschmer K, Apostolou I, Hawiger D, Khazaie K, Nussenzweig MC, von Boehmer H (2005) Inducing and expanding regulatory T cell populations by foreign antigen. Nat Immunol 6:1219-1227

Krüger T, Benke D, Eitner F, Lang A, Wirtz M, Hamilton-Williams EE, Engel D, Giese B, Müller-Newen G, Floege J, Kurts C (2004) 
Identification and functional characterization of dendritic cells in the healthy murine kidney and in experimental glomerulonephritis. J Am Soc Nephrol 15:613-621

Kruse N, Neumann K, Schrage A, Derkow K, Schott E, Erben U, Kühl A, Loddenkemper C, Zeitz M, Hamann A, Klugewitz K (2009) Priming of CD4+ T cells by liver sinusoidal endothelial cells induces CD25low forkhead box protein 3- regulatory $\mathrm{T}$ cells suppressing autoimmune hepatitis. Hepatology 50:1904-1913

Kurts C, Panzer U, Anders HJ, Rees AJ (2013) The immune system and kidney disease: Basic concepts and clinical implications. Nat Rev Immunol 13:738-753

Lee H, Nho D, Chung HS, Lee H, Shin MK, Kim SH, Bae H (2010) $\mathrm{CD} 4+\mathrm{CD} 25+$ regulatory $\mathrm{T}$ cells attenuate cisplatin-induced nephrotoxicity in mice. Kidney Int 78:1100-1109

Lee VW, Harris DC (2011) Adriamycin nephropathy: A model of focal segmental glomerulosclerosis. Nephrology 16:30-38

Levings MK, Gregori S, Tresoldi E, Cazzaniga S, Bonini C, Roncarolo MG (2005) Differentiation of Tr1 cells by immature dendritic cells requires IL-10 but not CD25+CD4+ Tr cells. Blood 105:1162-1169

Liang H, Xu F, Wen XJ, Liu HZ, Wang HB, Zhong JY, Yang CX, Zhang B (2017) Interleukin-33 signaling contributes to renal fibrosis following ischemia reperfusion. Eur J Pharmacol 812:18-27

Liao W, Zheng H, Wu S, Zhang Y, Wang W, Zhang Z, Zhou C, Wu H, Min J (2017) The systemic activation of programmed death 1-PD-L1 axis protects systemic lupus erythematosus model from nephritis. Am J Nephrol 46:371-379

Lin FJ, Jiang GR, Shan JP, Zhu C, Zou J, Wu XR (2012) Imbalance of regulatory $\mathrm{T}$ cells to Th17 cells in $\mathrm{IgA}$ nephropathy. Scand $\mathrm{J}$ Clin Lab Invest 72:221-229

Linker-Israeli M, Bakke AC, Kitridou RC, Gendler S, Gillis S, Horwitz DA (1983) Defective production of interleukin 1 and interleukin 2 in patients with systemic lupus erythematosus (SLE). J Immunol 130:2651-2655

Liu M, Chien CC, Burne-Taney M, Molls RR, Racusen LC, Colvin RB, Rabb H (2006) A pathophysiologic role for T lymphocytes in murine acute cisplatin nephrotoxicity. J Am Soc Nephrol 17:765-774

Lochner M, Peduto L, Cherrier M, Sawa S, Langa F, Varona R, Riethmacher D, Si-Tahar M, Di Santo JP, Eberl G (2008) In vivo equilibrium of proinflammatory IL-17+ and regulatory IL-10+ Foxp3+ ROR $\gamma \mathrm{t}+\mathrm{T}$ cells. J Exp Med 205:1381-1393

Lu J, Cao Q, Zheng D, Sun Y, Wang C, Yu X, Wang Y, Lee VW, Zheng G, Tan TK, Wang X, Alexander SI, Harris DC, Wang Y (2013) Discrete functions of M2a and M2c macrophage subsets determine their relative efficacy in treating chronic kidney disease. Kidney Int 84:745-755

Lu LF, Lind EF, Gondek DC, Bennett KA, Gleeson MW, Pino-Lagos K, Scott ZA, Coyle AJ, Reed JL, Van Snick J, Strom TB, Zheng XX, Noelle RJ (2006) Mast cells are essential intermediaries in regulatory T-cell tolerance. Nature 442:997-1002

Mahajan D, Wang Y, Qin X, Wang Y, Zheng G, Wang YM, Alexander SI, Harris DC (2006) CD4+CD25+ regulatory T cells protect against injury in an innate murine model of chronic kidney disease. J Am Soc Nephrol 17:2731-2741

Malek TR, Yu A, Vincek V, Scibelli P, Kong L (2002) CD4 regulatory $\mathrm{T}$ cells prevent lethal autoimmunity in IL-2R $\beta$-deficient mice: Implications for the nonredundant function of IL-2. Immunity $17: 167-178$

Manohar S, Leung N (2018) Cisplatin nephrotoxicity: A review of the literature. J Nephrol 31:15-25

Mauri C, Bosma A (2012) Immune Regulatory Function of B Cells. Annu Rev Immunol 30:221-241

Menke J, Lucas JA, Zeller GC, Keir ME, Huang XR, Tsuboi N, Mayadas TN, Lan HY, Sharpe AH, Kelley VR (2007) Programmed death 1 ligand (PD-L) 1 and PD-L2 limit autoimmune kidney disease: distinct roles. J Immunol 179:7466-7477
Min B (2017) Heterogeneity and stability in Foxp3+ regulatory T cells. J Interf Cytokine Res 37:386-397

Miyara M, Gorochov G, Ehrenstein M, Musset L, Sakaguchi S, Amoura Z (2011) Human FoxP3 + regulatory T cells in systemic autoimmune diseases. Autoimmun Rev 10:744-755

Morgan MD, Day CJ, Piper KP, Khan N, Harper L, Moss PA, Savage CO (2010) Patients with Wegener's granulomatosis demonstrate a relative deficiency and functional impairment of T-regulatory cells. Immunology 130(1):64-73

Neumann K, Ostmann A, Breda PC, Ochel A, Tacke F, Paust HJ, Panzer U, Tiegs G (2019) The co-inhibitory molecule PD-L1 contributes to regulatory $\mathrm{T}$ cell-mediated protection in murine crescentic glomerulonephritis. Sci Rep 9:2038

Nie H, Zheng Y, Li R, Guo TB, He D, Fang L, Liu X, Xiao L, Chen X, Wan B, Chin YE, Zhang JZ (2013) Phosphorylation of FOXP3 controls regulatory $\mathrm{T}$ cell function and is inhibited by TNF- $\alpha$ in rheumatoid arthritis. Nat Med 19:322-328

Nikolic-Paterson DJ, Atkins RC (2001) The role of macrophages in glomerulonephritis. Nephrol Dial Transplant 16(Suppl 5):3-7

Nishimura H, Nose M, Hiai H, Minato N, Honjo T (1999) Development of lupus-like autoimmune diseases by disruption of the PD-1 gene encoding an ITIM motif-carrying immunoreceptor. Immunity 11:141-151

Nosko A, Kluger MA, Diefenhardt P, Melderis S, Wegscheid C, Tiegs G, Stahl RA, Panzer U, Steinmetz OM (2017) T-bet enhances regulatory $\mathrm{T}$ cell fitness and directs control of th1 responses in Crescentic GN. J Am Soc Nephrol 28:185-196

Obregon C, Kumar R, Pascual MA, Vassalli G, Golshayan D (2017) Update on dendritic cell-induced immunological and clinical tolerance. Front Immunol 8:1514

Ochando JC, Homma C, Yang Y, Hidalgo A, Garin A, Tacke F, Angeli V, Li Y, Boros P, Ding Y, Jessberger R, Trinchieri G, Lira SA, Randolph GJ, Bromberg JS (2006) Alloantigen-presenting plasmacytoid dendritic cells mediate tolerance to vascularized grafts. Nat Immunol 7:652-662

Ochel A, Tiegs G, Neumann K (2019) Type 2 innate lymphoid cells in liver and gut: From current knowledge to future perspectives. Int J Mol Sci 20:1896

Odobasic D, Gan PY, Summers SA, Semple TJ, Muljadi RC, Iwakura Y, Kitching AR, Holdsworth SR (2011) Interleukin-17A promotes early but attenuates established disease in crescentic glomerulonephritis in mice. Am J Pathol 179:1188-1198

Odobasic D, Oudin V, Ito K, Gan PY, Kitching AR, Holdsworth SR (2019) Tolerogenic dendritic cells attenuate experimental autoimmune antimyeloperoxidase glomerulonephritis. J Am Soc Nephrol 30:2140-2157

Okazaki T, Honjo T (2007) PD-1 and PD-1 ligands: From discovery to clinical application. Int Immunol 19:813-824

Okusa MD, Linden J, Macdonald T, Huang L (1999) Selective A(2A) adenosine receptor activation reduces ischemia-reperfusion injury in rat kidney. Am J Physiol - Ren Physiol 277:F404-F412

Ooi JD, Petersen J, Tan YH, Huynh M, Willett ZJ, Ramarathinam SH, Eggenhuizen PJ, Loh KL, Watson KA, Gan PY, Alikhan MA, Dudek NL, Handel A, Hudson BG, Fugger L, Power DA, Holt SG, Coates PT, Gregersen JW, Purcell AW, Holdsworth SR, La Gruta NL, Reid HH, Rossjohn J, Kitching AR (2017) Dominant protection from HLA-linked autoimmunity by antigen-specific regulatory T cells. Nature 545:243-247

Ooi JD, Snelgrove SL, Engel DR, Hochheiser K, Ludwig-Portugall I, Nozaki Y, O'Sullivan KM, Hickey MJ, Holdsworth SR, Kurts C, Kitching AR (2011) Endogenous foxp3+ T-regulatory cells suppress anti-glomerular basement membrane nephritis. Kidney Int 79:977-986

Osorio F, LeibundGut-Landmann S, Lochner M, Lahl K, Sparwasser T, Eberl G, Reis e Sousa C, (2008) DC activated via dectin-1 convert Treg into IL-17 producers. Eur J Immunol 38:3274-3281 
Ostmann A, Paust HJ, Panzer U, Wegscheid C, Kapffer S, Huber S, Flavell RA, Erhardt A, Tiegs G (2013) Regulatory T cell-derived IL-10 ameliorates crescentic GN. J Am Soc Nephrol 24:930-942

Panduro M, Benoist C, Mathis D (2016) Tissue Tregs. Annu Rev Immunol 34:609-633

Paust HJ, Ostmann A, Erhardt A, Turner JE, Velden J, Mittrücker HW, Sparwasser T, Panzer U, Tiegs G (2011) Regulatory T cells control the Th1 immune response in murine crescentic glomerulonephritis. Kidney Int 80:154-164

Paust HJ, Riedel JH, Krebs CF, Turner JE, Brix SR, Krohn S, Velden J, Wiech T, Kaffke A, Peters A, Bennstein SB, Kapffer S, MeyerSchwesinger C, Wegscheid C, Tiegs G, Thaiss F, Mittruicker HW, Steinmetz OM, Stahl RA, Panzer U (2016) CXCR3+ regulatory T cells control TH1 responses in crescentic GN. J Am Soc Nephrol 27:1933-1942

Paust HJ, Turner JE, Steinmetz OM, Peters A, Heymann F, Hölscher C, Wolf G, Kurts C, Mittrücker HW, Stahl RA, Panzer U (2009) The IL-23/Th17 axis contributes to renal injury in experimental glomerulonephritis. J Am Soc Nephrol 20:969-979

Phelps RG, Rees AJ (1999) The HLA complex in goodpasture's disease: A model for analyzing susceptibility to autoimmunity. Kidney Int 56:1638-1653

Phoon RK, Kitching AR, Odobasic D, Jones LK, Semple TJ, Holdsworth SR (2008) T-bet deficiency attenuates renal injury in experimental crescentic glomerulonephritis. J Am Soc Nephrol 19:477-485

Polansky JK, Kretschmer K, Freyer J, Floess S, Garbe A, Baron U, Olek S, Hamann A, von Boehmer H, Huehn J (2008) DNA methylation controls Foxp3 gene expression. Eur J Immunol 38:1654-1663

Polhill T, Zhang GY, Hu M, Sawyer A, Zhou JJ, Saito M, Webster KE, Wang Y, Wang Y, Grey ST, Sprent J, Harris DC, Alexander SI, Wang YM (2012) IL-2/IL-2Ab complexes induce regulatory T cell expansion and protect against proteinuric CKD. J Am Soc Nephrol 23:1303-1308

Prokunina L, Castillejo-López C, Oberg F, Gunnarsson I, Berg L, Magnusson V, Brookes AJ, Tentler D, Kristjansdóttir H, Gröndal G, Bolstad AI, Svenungsson E, Lundberg I, Sturfelt G, Jönssen A, Truedsson L, Lima G, Alcocer-Varela J, Jonsson R, Gyllensten UB, Harley JB, Alarcón-Segovia D, Steinsson K, Alarcón-Riquelme ME (2002) A regulatory polymorphism in PDCD1 is associated with susceptibility to systemic lupus erythematosus in humans. Nat Genet 32:666-669

Qin XH, Lee VW, Wang YP, Zheng GP, Wang Y, Alexander SI, Harris DC (2006) A protective role for programmed death 1 in progression of murine adriamycin nephropathy. Kidney Int 70:1244-1250

Rahman A, Isenberg DA (2008) Systemic lupus erythematosus. N Engl J Med 358:929-939

Reynolds J, Sando GS, Marsh OB, Salama AD, Evans DJ, Cook HT, Pusey CD (2012) Stimulation of the PD-1/PDL-1 T-cell co-inhibitory pathway is effective in treatment of experimental autoimmune glomerulonephritis. Nephrol Dial Transplant 27:1343-1350

Riedel JH, Becker M, Kopp K, Düster M, Brix SR, Meyer-Schwesinger C, Kluth LA, Gnirck AC, Attar M, Krohn S, Fehse B, Stahl RAK, Panzer U, Turner JE (2017) IL-33-Mediated expansion of type 2 innate lymphoid cells protects from progressive glomerulosclerosis. J Am Soc Nephrol 28:2068-2080

Rimbert M, Hamidou M, Braudeau C, Puéchal X, Teixeira L, Caillon H, Néel A, Audrain M, Guillevin L (2011) Decreased numbers of blood dendritic cells and defective function of regulatory $\mathrm{T}$ cells in antineutrophil cytoplasmic antibody-associated vasculitis. PLOS ONE 6:e18734

Riquelme P, Haarer J, Kammler A, Walter L, Tomiuk S, Ahrens N, Wege AK, Goecze I, Zecher D, Banas B, Spang R, Fändrich F, Lutz MB, Sawitzki B, Schlitt HJ, Ochando J, Geissler EK, Hutchinson JA (2018) TIGIT+ iTregs elicited by human regulatory macrophages control $\mathrm{T}$ cell immunity. Nat Commun 9:2858
Roediger B, Kyle R, Yip KH, Sumaria N, Guy TV, Kim BS, Mitchell AJ, Tay SS, Jain R, Forbes-Blom E, Chen X, Tong PL, Bolton HA, Artis D, Paul WE, de St F, Groth B, Grimbaldeston MA, Le Gros G, Weninger W (2013) Cutaneous immunosurveillance and regulation of inflammation by group 2 innate lymphoid cells. Nat Immunol 14:564-573

Romano M, Fanelli G, Albany CJ, Giganti G, Lombardi G (2019) Past, present, and future of regulatory $\mathrm{T}$ cell therapy in transplantation and autoimmunity. Front Immunol 10:43

Sabapathy V, Cheru NT, Corey R, Mohammad S, Sharma R (2019) A novel hybrid cytokine IL233 mediates regeneration following doxorubicininduced nephrotoxic injury. Sci Rep 9:3215

Sakaguchi S, Yamaguchi T, Nomura T, Ono M (2008) Regulatory T cells and immune tolerance. Cell 133:775-787

Salama AD, Chaudhry AN, Holthaus KA, Mosley K, Kalluri R, Sayegh MH, Lechler RI, Pusey CD, Lightstone L (2003) Regulation by CD25+ lymphocytes of autoantigen-specific T-cell responses in Goodpasture's (anti-GBM) disease. Kidney Int 64:1685-1694

Savage ND, de Boer T, Walburg KV, Joosten SA, van Meijgaarden K, Geluk A, Ottenhoff TH (2008) Human anti-inflammatory macrophages induce Foxp3+ GITR+ CD25+ regulatory T cells, which suppress via membrane-bound TGFbeta-1. J Immunol 181:2220-2226

Schiering C, Krausgruber T, Chomka A, Fröhlich A, Adelmann K, Wohlfert EA, Pott J, Griseri T, Bollrath J, Hegazy AN, Harrison OJ, Owens BMJ, Löhning M, Belkaid Y, Fallon PG, Powrie F (2014) The alarmin IL-33 promotes regulatory T-cell function in the intestine. Nature 513:564-568

Schildberg FA, Hegenbarth SI, Schumak B, Scholz K, Limmer A, Knolle PA (2008) Liver sinusoidal endothelial cells veto CD8 T cell activation by antigen-presenting dendritic cells. Eur J Immunol 38:957-967

Schlondorff DO (2008) Overview of factors contributing to the pathophysiology of progressive renal disease. Kidney Int 74:860-866

Schmidt A, Zhang XM, Joshi RN, Iqbal S, Wahlund C, Gabrielsson S, Harris RA, Tegnér J (2016) Human macrophages induce CD4(+) Foxp3(+) regulatory $\mathrm{T}$ cells via binding and re-release of TGF- $\beta$. Immunol Cell Biol 94:747-762

Schroll A, Eller K, Huber JM, Theurl IM, Wolf AM, Weiss G, Rosenkranz AR (2010) Tim 3 is upregulated and protective in nephrotoxic serum nephritis. Am J Pathol 176:1716-1724

Setoguchi R, Hori S, Takahashi T, Sakaguchi S (2005) Homeostatic maintenance of natural Foxp3+ CD25+CD4+ regulatory T cells by interleukin (IL)-2 and induction of autoimmune disease by IL-2 neutralization. J Exp Med 201:723-735

Sharma R, Kinsey GR (2018) Regulatory T cells in acute and chronic kidney diseases. Am J Physiol Physiol 314:F679-F698

Sharma R, Sharma PR, Kim YC, Leitinger N, Lee JK, Fu SM, Ju ST (2011) IL-2-controlled expression of multiple T cell trafficking genes and Th2 cytokines in the regulatory T cell-deficient scurfy mice: Implication to multiorgan inflammation and control of skin and lung inflammation. J Immunol 186:1268-1278

Shevach EM (2009) Mechanisms of Foxp3+ T regulatory cell-mediated suppression. Immunity 30:636-645

Sinclair GD, Wadgymar A, Halloran PF, Delovitch TL (1984) Graft-vs-host reactions induce $\mathrm{H}-2$ class II gene transcription in host kidney cells. Immunogenetics 20:503-511

Song YC, Tang SJ, Lee TP, Hung WC, Lin SC, Tsai CY, Ng WV, Wu MF, Sun KH (2010) Reversing interleukin-2 inhibition mediated by antidouble-stranded DNA autoantibody ameliorates glomerulonephritis in MRL-lpr/lpr mice. Arthritis Rheum 62:2401-2411

Starke A, Lindenmeyer MT, Segerer S, Neusser MA, Rüsi B, Schmid DM, Cohen CD, Wüthrich RP, Fehr T, Waeckerle-Men Y (2010) Renal tubular PD-L1 (CD274) suppresses alloreactive human T-cell responses. Kidney Int 78:38-47

Steinmann S, Schoedsack M, Heinrich F, Breda PC, Ochel A, Tiegs G, Neumann K (2020) Hepatic ILC2 activity is regulated by liver 
inflammation-induced cytokines and effector CD4+ T cells. Sci Rep 10:1071

Steinmetz OM, Summers SA, Gan PY, Semple T, Holdsworth SR, Kitching AR (2011) The Th17-defining transcription factor ROR $\gamma \mathrm{t}$ promotes glomerulonephritis. J Am Soc Nephrol 22:472-483

Stremska ME, Jose S, Sabapathy V, Huang L, Bajwa A, Kinsey GR, Sharma PR, Mohammad S, Rosin DL, Okusa MD, Sharma R (2017) IL233, A novel IL-2 and IL-33 hybrid cytokine, ameliorates renal injury. J Am Soc Nephrol 28:2681-2693

Sung SJ, Li L, Huang L, Lawler J, Ye H, Rosin DL, Vincent IS, Le TH, Yu J, Görldt N, Schrader J, Okusa MD (2017) Proximal tubule CD73 is critical in renal ischemia-reperfusion injury protection. J Am Soc Nephrol 74:1526-1537

Tai N, Yasuda H, Xiang Y, Zhang L, Rodriguez-Pinto D, Yokono K, Sherwin R, Wong FS, Nagata M, Wen L (2011) Clin Immunol 139:336-349

Tan DS, Gan PY, O'Sullivan KM, Hammett MV, Summers SA, Ooi JD, Lundgren BA, Boyd RL, Scott HS, Kitching AR, Chidgey AP, Holdsworth SR (2013) Thymic deletion and regulatory t cells prevent antimyeloperoxidase GN. J Am Soc Nephrol 24:573-585

Teichmann LL, Kashgarian M, Weaver CT, Roers A, Müller W, Shlomchik MJ (2012) B cell-derived IL-10 does not regulate spontaneous systemic autoimmunity in MRL.Fas lpr mice. J Immunol 188:678-685

Timoshanko JR, Kitching AR, Semple TJ, Tipping PG, Holdsworth SR (2006) A pathogenetic role for mast cells in experimental crescentic glomerulonephritis. J Am Soc Nephrol 17:150-159

Tipping PG, Huang XR, Qi M, Van GY, Tang WW (1998) Crescentic glomerulonephritis in CD4- and CD8-deficient mice: Requirement for CD4 but not CD8 cells. Am J Pathol 152:1541-1548

Tóth T, Tóth-Jakatics R, Jimi S, Ihara M, Urata H, Takebayashi S (1999) Mast cells in rapidly progressive glomerulonephritis. J Am Soc Nephrol 10:1498-1505

Trautmann A (2009) Extracellular ATP in the immune system: More than just a "danger signal." Sci Signal 2:pe6

Travis MA, Reizis B, Melton AC, Masteller E, Tang Q, Proctor JM, Wang Y, Bernstein X, Huang X, Reichardt LF, Bluestone JA, Sheppard D (2007) Loss of integrin alpha(v)beta8 on dendritic cells causes autoimmunity and colitis in mice. Nature 449:361-365

von Spee-Mayer C, Siegert E, Abdirama D, Rose A, Klaus A, Alexander T, Enghard P, Sawitzki B, Hiepe F, Radbruch A, Burmester GR, Riemekasten G, Humrich JY (2016) Low-dose interleukin-2 selectively corrects regulatory $\mathrm{T}$ cell defects in patients with systemic lupus Erythematosus. Ann Rheum Dis 75:1407-1415

Waeckerle-Men Y, Starke A, Wahl PR, Wüthrich RP (2007) Limited costimulatory molecule expression on renal tubular epithelial cells impairs T cell activation. Kidney Blood Press Res 30:421-429

Wakkach A, Fournier N, Brun V, Breittmayer JP, Cottrez F, Groux H (2003) Characterization of dendritic cells that induce tolerance and $\mathrm{T}$ regulatory 1 cell differentiation in vivo. Immunity 18:605-617

Wang X, Szymczak-Workman AL, Gravano DM, Workman CJ, Green DR, Vignali DA (2012) Preferential control of induced regulatory $\mathrm{T}$ cell homeostasis via a Bim/Bcl-2 axis. Cell Death Dis 3:e270
Wang Y, Chang J, Yao B, Niu A, Kelly E, Breeggemann MC, Abboud Werner SL, Harris RC, Zhang MZ (2015) Proximal tubulederived colony stimulating factor-1 mediates polarization of renal macrophages and dendritic cells, and recovery in acute kidney injury. Kidney Int 88:1274-1282

Wang YM, Zhang GY, Wang Y, Hu M, Wu H, Watson D, Hori S, Alexander IE, Harris DC, Alexander SI (2006) Foxp3-transduced polyclonal regulatory $\mathrm{T}$ cells protect against chronic renal injury from adriamycin. J Am Soc Nephrol 17:697-706

Wang Y, Wang YP, Zheng G, Lee VW, Ouyang L, Chang DH, Mahajan D, Coombs J, Wang YM, Alexander SI, Harris DC (2007) Ex vivo programmed macrophages ameliorate experimental chronic inflammatory renal disease. Kidney Int 72:290-299

Wilkinson R, Wang X, Roper KE, Healy H (2011) Activated human renal tubular cells inhibit autologous immune responses. Nephrol Dial Transplant 26:1483-1492

Wolf D, Hochegger K, Wolf AM, Rumpold HF, Gastl G, Tilg H, Mayer G, Gunsilius E, Rosenkranz AR (2005) CD4+CD25+ regulatory $\mathrm{T}$ cells inhibit experimental anti-glomerular basement membrane glomerulonephritis in mice. J Am Soc Nephrol 16:1360-1370

Wuthrich RP, Yui MA, Mazoujian G, Nabavi N, Glimcher LH, Kelley VE (1989) Enhanced MHC class II expression in renal proximal tubules precedes loss of renal function in MRL/lpr mice with lupus nephritis. Am J Pathol 134:45-51

Yan JJ, Lee JG, Jang JY, Koo TY, Ahn C, Yang J (2017) IL-2/ anti-IL-2 complexes ameliorate lupus nephritis by expansion of CD4+CD25+Foxp3+ regulatory T cells. Kidney Int 91:603-615

Yang L, Zhang XY, Peng W, Wei M, Qin W (2017) MicroRNA-155induced T lymphocyte subgroup drifting in IgA nephropathy. Int Urol Nephrol 49:353-361

Zaiss DM, van Loosdregt J, Gorlani A, Bekker CP, Gröne A, Sibilia M, van Bergen en Henegouwen PM, Roovers RC, Coffer PJ, Sijts AJ, (2013) Amphiregulin enhances regulatory $\mathrm{T}$ cell-suppressive function via the epidermal growth factor receptor. Immunity 38:275-284

Zhang C, Li L, Feng K, Fan D, Xue W, Lu J (2017) "Repair" Treg cells in tissue injury. Cell Physiol Biochem 43:2155-2169

Zhang Q, Luan H, Wang L, He F, Zhou H, Xu X, Li X, Xu Q, Niki T, Hirashima M, Xu G, Lv Y, Yuan J (2014) Galectin-9 ameliorates anti-GBM glomerulonephritis by inhibiting th1 and th17 immune responses in mice. Am J Physiol - Ren Physiol 306:F822-F832

Zhang MZ, Wang X, Wang Y, Niu A, Wang S, Zou C, Harris RC (2017) IL-4/IL-13-mediated polarization of renal macrophages/ dendritic cells to an M2a phenotype is essential for recovery from acute kidney injury. Kidney Int 91:375-386

Zheng D, Wang Y, Cao Q, Lee VW, Zheng G, Sun Y, Tan TK, Wang Y, Alexander SI, Harris DC (2011) Transfused macrophages ameliorate pancreatic and renal injury in murine diabetes mellitus. Nephron Exp Nephrol 118:e87-99

Publisher's Note Springer Nature remains neutral with regard to jurisdictional claims in published maps and institutional affiliations. 